\title{
Winieta latarni morskiej w La Coruña na mapie Beatusa z Burgo de Osma w kontekście symboliki wczesnochrześcijańskiej
}

Dobrze znana mapa Beatusa z Burgo de Osma (fig. 1)², która powstała w roku 1086, jest jedną z 71 miniatur, jakie zawiera kodeks (166 kart pergaminowych, każda o wymiarach $360 \times 253 \mathrm{~mm})^{3}$ przechowywany w archi-

1 Dr hab. Piotr Kochanek, kierownik Katedry Historii Starożytnej i Bizantyńskiej w Instytucie Historii na Wydziale Nauk Humanistycznych Katolickiego Uniwersytetu Lubelskiego Jana Pawła II, e-mail: lu2005harn@yahoo.de, ORCID: 0000-0001-9702-548X.

2 Mapa Beatusa z Burgo de Osma. Źródło oryginału: Burgo de Osma, Archivo de la Catedral, Ms 1, fol. 34v-35r (data powstania: 1086; wielkość oryginału: 300 x 380 mm). Tekst legend mapy: K. Miller, Mappaemundi. Die ältesten Weltkarten, t. 1, Stuttgart 1895, 34-36; G. Menéndez-Pidal, Mozárabes y Asturianos en la cultura de la alta Edad Media en relación especial con la historia de los conocimientos geográficos, „Boletin de la Real Academia de la Historia” 134 (1954) 258 (legendy znajdują się na przerysie mapy); H. García-Aráez, Los mapamundis de los Beatos, cz. 2, „Miscelánea Medieval Murciana” 1920 (1995-1996) 100-123. Fragmenty tekstu legend mapy: A.-D. von den Brincken, Fines Terrae. Die Enden der Erde und der vierte Kontinent auf mittelalterlichen Weltkarten, Monumenta Germaniae Historica. Schriften 36, Hannover 1992, 151, 17. Źródło kopii: B. English, Ordo orbis terrae. Die Weltsicht in den Mappae mundi der frühen und hohen Mittelalters, Orbis Mediaevalis 3, Berlin 2002, 345, fig. 61. Por. M.T. Nurminen, Die Welt in Karten. Meisterwerke der Kartographie, tt. G. Beitscher - G. Seidel, Darmstadt 2017, 36.

3 Por. T. Rojo Orcajo, Catálogo descriptivo de los códices que se conservan en la Santa Iglesia Catedral de Burgo de Osma, „Boletín de la Real Academia de la Historia” 94 (1929) 667 (T. Rojo Orcajo, Catálogo descriptivo de los códices que se conservan en la Santa Iglesia Catedral de Burgo de Osma, Madrid 1929, 17); J. Williams, Visions of the End in Medieval Spain. Catalogue of Illustrated Beatus Commentary on the Apocalypse and the Study of the Geneva Beatus, red. T. Martin, Late Antique and Early Medieval 
wum katedralnym w Burgo de Osma ${ }^{4}$. Kodeks ten jest jedną z 29, zachowanych w całości lub fragmentarycznie, ilustrowanych kopii „Komentarza do Apokalipsy"5. Oryginał tego dzieła został napisany w latach 776-786 przez Beatusa z Lièbana (ok. 730-798), opata benedyktyńskiego klasztoru San Martín de Liébana 6 . Wspomniana mapa ma za zadanie zilustrowanie idei

Iberia 3, Amsterdam 2017, 105; T. Martin - J. Williams, Women's Spaces - Real and Imagined - in the Illustrated Beatus Commentaries, „Arenal” 25 (2018) nr 2, 389.

4 Por. J. Williams, The Illustrated Beatus. A Corpus of the Illustrations of the Commentary on the Apocalypse, t. 4, London 2002, 17-25. Por. też B.A. Shailor, The Beatus of Burgo de Osma: A Paleographical and Codicological Studies, w: Apocalipsis Beati Liebanensis Burgi Oxomensis, t. 2, tł. A. Baloira, Valencia 1992, 29-52; J. Williams, Las ilustraciones del Beato de Burgo de Osma, w: Apocalipsis Beati Liebanensis Burgi Oxomensis, t. 2, t1. A. Baloira, Valencia 1992, 109-150.

5 Por. Williams, Visions of the End in Medieval Spain, s. 67-148 (2. The Census. A Complet Register of Illustrated Beatus Commentaries and Fragments); Martin Williams, Women's Spaces, s. 388-390 (Appendix A. List of the Illustrated Beatus Commentaries). Por. też J. Strzelczyk, Gerwazy z Tilbury. Studium z dziejów uczoności geograficznej w średniowieczu, Monografie z Dziejów Nauki i Techniki 66, Wrocław Warszawa 1970, 209. Na temat rzeczonych kodeksów istnieje obszerna literatura, por. G.G. King, Divagations on the Beatus, „Art Studies. Medieval Renaissance and Modern” 8 (1930) nr 1, 3-58; W. Neuss, Die Apokalypse des Hl. Johannes in der altspanischen und altchristlichen Bibel-Illustration (Das Problem der Beatus-Handschriften), t. 1-2, Spanische Forschungen der Görresgesellschaft Reihe II/2-3, Münster 1931; H. Stierlin, Los Beatos de Liébana y el arte mozárabe, Madrid 1983; J. Yarza Luaces, Beato de Liébana: Manuscriptos iluminados, Barcelona 1998; E.S. Bolman, De coloribus: The Meanings of Color in Beatus Manuscripts, „Gesta” 38 (1999) nr 1, 22-34; P.K. Klein, Beatus de Liébana, Codex Urgellensis. Kommentarband zur Facsimile-Ausgabe, Madrid 2001; Williams, The Illustrated Beatus, t. 1-5, London 1994-2003; Seis estudios sobre Beatos medievales, red. M. Pérez, Leon 2010; P. Roszak, Beato z Liébany i mozarabskie komentarze do Apokalipsy, BPTh 5 (2012) 125-147.

6 Aktualnie funkcjonują trzy wydania krytyczne tego dzieła. Autorem pierwszego jest Henry Arthur Sanders (22 X 1868-16 XI 1956 - Beati in Apocalipsin libri duodecim, red. H.A. Sanders, Papers and Monographs of the American Academy in Rome 7, Rome 1930), drugie sporządził bp Eugenio Romero Pose (15 III 1949-25 III 2007 Sancti Beati a Liebana Commentarius in Apocalypsin, ed. E. Romero Pose, t. 1-2, Romae 1985). wreszcie najnowsza edycja krytyczna jest efektem pracy Rogera Grysona: Beati Liebanensis Tractatus de Apocalipsin, red. R. Gryson, CCL 107B-C, Turnhout 2012. Istnieje również wersja z roku 1770, której autorem był Henricus Florez (21 VII 1702-20 VIII 1773): Sancti Beati, Presbyteri Hispani Liebanensis, in Apocalypsin, ac plurimas utriusque Foederis paginas commentaria, ex veteribus, nonnullisque desideratis Patribus, mille retro annis collecta, nunc primum edita, ed. H. Florey, Matriti 1770. 
„rozesłania Apostołów”, o której mowa w komentarzu7, i jest jedną z piętnastu zachowanych do dziś map typu Beatus ${ }^{8}$. Ponadto mapa typu Beatus widniała również jako malowidło ścienne w niewielkiej świątyni San Pedro de Rocas, w południowo-galicyjskiej prowincji Orense ${ }^{9}$. To, co wyróżnia

7 Beatus Liebanensis, Tractatus de Apocalipsin, Prologus II 3, 17-18, 77-88, red. R. Gryson, CCL 107B, Turnhout 2012, 163.

8 Do ważnych prac na temat map Beatusa jako takich należą, obok wyżej wymienionych (przyp. 2) publikacji Konrada Millera (21 XI 1844-25 VII 1933), Gonzalo Menéndez-Pidala (12 IV 1911-11 XII 208) oraz Brigitte Englisch, również teksty, których autorami są Marcel Destombes (27 VII-26 XI 1983) - Mappemondes A.D. 1200-1500. Catalogue prepare par la Commission des Cartes Anciennes de l'Union Géographique Internationale, Monumenta Cartographica Vetustioris Aevi I, Amsterdam 1964, 40-42 (17,1-13) oraz 79-84 (35,1-2); Serafín Moralejo Álvarez (31 X 1946-11 VIII 2011) El mundo y el tiempo en el mapa de Beato de Osma, w: Apocalipsis Beati Liebanensis Burgi Oxomensis, t. 2, tt. A. Baloira, Valencia 1992, 151-179 (= Patrimonio artístico de Galicia y otros estudios. Homenaje al Prof. Dr. Serafin Moralejo Álvarez, t. 2, red. M.Á. Franco Mata, Santiago de Compostela 2004, 237-260); John Williams (25 II 1928-6 VI 2015) - Isidore, Orosius and the Beatus Map, „Imago Mundi” 49 (1997) 7-32; Ingrid Baumgärtner - Visualisierte Weltenräume. Tradition und Innovation in den Weltkarten der Beatustradition des 10. bis 13. Jahrhunderts, w: Tradition, Innovation, Invention. Fortschrittsverweigerung und Fortschrittsbewusstsein im Mittelalter, red. H.-J. Schmidt, Scrinium Friburgense 18, Berlin - New York 2005, 231-276; Graphische Gestalt und Signifikanz. Europa in den Weltkarten des Beatus von Liébana und des Ranulf Hidgen, w: Europa im Weltbild des Mittelalters. Kartographische Konzepte, red. I. Baumgärtner - H. Kugler, Orbis Mediaevalis 10, Berlin 2008, 83-101; Leonid S. Chekin - Northern Eurasia in Medieval Cartography. Inventory, Text, Translation, and Commentary, Terrarum Orbis 4, Turnhout 2006, 171-179 (XI 1-5.); Rouben Galichian - Countries south of the Caucasus in Medieval Maps. Armenia, Georgia and Azerbaijan, London 2007, 66-81; Thomas Deswarte - Géographie sacrée ou géographie du sacré? Les mappemondes du Commentaire de Beatus aux $X^{\mathrm{e}}$ et XI siècles, w: De l'espace aux territoires: la territorialité des processus sociaux et culturels au Moyen Âge, Actes de la table ronde des 8-9 juin 2006, CESM (Poitiers), red. S. Boissellier, Culture et Société Médiévales 19, Turnhout 2010, 113-131; Sandra Sáenz-López Pérez - Peregrinatio in stabilitate: transformación de un mapa de los Beatos en herramienta de peregrinación espiritual, „Anales de Historia del Arte", volumen extraordinario (2011) 317-334; The Beatus Maps: The Revelation of the World in the Middle Ages, tł. P. Krakenberger - G. Coldham, Burgos 2014. Por. też: Strzelczyk, Gerwazy z Tilbury, s. 208-212; P. Kochanek, „Rozesłanie Apostołów” na mapie Beatusa z Burgo de Osma, w: Fructus Spiritus est Caritas, Ksiega Jubileuszowa ofiarowana Księdzu Profesorowi Franciszkowi Drączkowskiemu z okazji siedemdziesiątej rocznicy urodzin, czterdziestolecia święceń kapłańskich i trzydziestopięciolecia pracy naukowej, red. M. Wysocki, Lublin 2011, 703-745 (zwłaszcza 703-713).

9 Por. J.M. García Iglesias, El mapa de los Beatos en la pintura mural románica de San Pedro de Rocas, „Archivos Leonenses” 69 (1981) 73-87; S. Moralejo Álvarez, Mapa 
mapę Beatusa z Burgo de Osma ze owego 15(16)-elementowego zbioru, to widoczne na niej „głowy/popiersia” Apostołów, które XI-wieczny miniaturzysta prawdopodobnie dodał (można też spotkać się z tezą, że powtórzył je za zaginionym dziś oryginałem mapy) w celu bardziej obrazowego połączenia swej mapy z treścią skopiowanego fragmentu komentarza. Być może również jednym z motywów jego działania był geopolityczny klimat epoki, który skłaniał do tego, aby pewne fakty z dziejów Kościoła okresu apostolskiego wyakcentować nie tylko werbalnie, lecz także graficznie ${ }^{10}$.

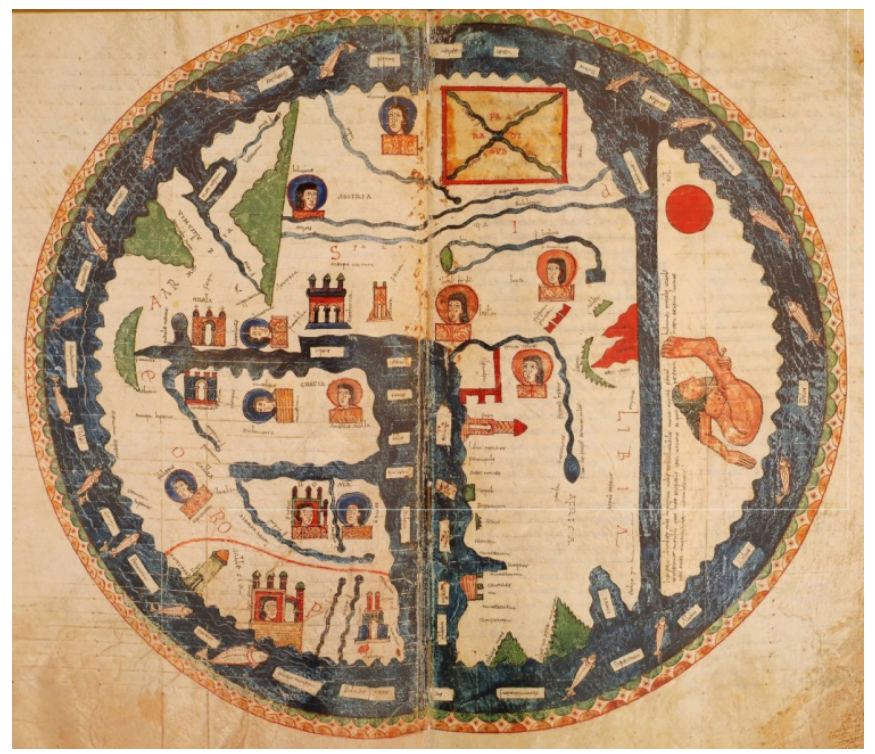

Fig. 1: Mapa Beatusa z Burgo de Osma (1086)

de la diáspora apostólica en San Pedro de Rocas: Notas para su interpretación y filiación en la tradición cartográfica de los „Beatos”, „Compostellanum” 31 (1986) nr 3-4, 315 340; Kochanek, ,, Rozesłanie Apostołów” na mapie Beatusa z Burgo de Osma, s. 735-738.

10 Por. Kochanek, „Rozesłanie Apostołów” na mapie Beatusa z Burgo de Osma, s. 714-735. Warto przypomnieć, że ,głowy/popiersia” apostolskie pojawiają się jeszcze na dwóch zachowanych mapach typu Beatus, a mianowicie na mapie Beatusa z Lorvão oraz na mapie Beatusa z Oña. Dostrzegalne były one także na mapie-fresku w kościele San Pedro de Rocas, gdzie istniała wspomniana wyżej (por. przyp. 9) szesnasta mapa typu Beatus, która jednak uległa zniszczeniu wskutek działania sił przyrody. por. Kochanek, „Rozesłanie Apostołów” na mapie Beatusa z Burgo de Osma, s. 735-738 (malowidło ścienne z San Pedro de Rocas), 738-739 (mapa Beatusa Lorvão), 740-741 (mapa Beatusa z Oña). 
Hiszpania ma na rzeczonej mapie nieco zniekształcony schemat trójkąta (fig. 2A), który to schemat w źródłach antycznych wspomina bodajże po raz pierwszy Orozjusz (380/385-ok. 450) ${ }^{11}$, a po nim przejmują go autorzy średniowieczni ${ }^{12}$. Wewnątrz tak przedstawionej Hiszpanii znajdują się trzy choronimy (Asturias, Gallecia i Spania), sześć toponimów (Corduba (?), Faro $=$ latarnia morska $\mathrm{w}$ La Coruña, Olisbona $=$ Lizbona, S. Jacobus $=$ Santiago de Compostela, Toletum $=$ Toledo i Terracon $a=$ Tarragona) oraz dwie nazwy $\operatorname{rzek}(F \text {. Durius }=\text { Duero i } F \text {. Minius }=\text { Miño })^{13} . \mathrm{W}$ kontekście niniejszych analiz ważny jest termin Faro, który, jak wyżej wspomniano, odnosi się do

11 Orosius, Historia adversus paganos I 2, 69, red. K. Zangemeister: Orosius, Historia adversus paganos. Liber apologeticus, CSEL 5, Wien 1882, 26, 10 (= PL 31, 688B).

12 Por. Cosmographia II 33, w: Geographi Latini Minores, s. 97, 25; Situs orbis terrae et regionum VII 17, red. P. Gautier Dalché: Situs orbis terre [sic !] vel regionum: Un traité de géographie inédit du haut Moyen Age (Paris, B. N. Latin 4841), „Revue d'Histoire des Textes" 12-13 (1982-1983) 171, 21; The Old English Orosius I 1, red. J. Bately: The Old English Orosius, The Early English Text Society. Supplementary Series 6, Oxford 1980, 19, 1; Hugo de Sancto Victore, Descriptio mappae mundi XXIII 622, red. P. Gautier Dalché: La „Descriptio mappe mundi” de Hugues de Saint-Victor. Texte inédit avec introduction et commentaire, Collection des Études Augustiniennes. Série Moyen Âge et Temps Modernes (20), Paris 1988, 156; Gervasius Tilleberiensis, Otia imperialia II 10, red. S.E. Banks - J.W. Binns: Gervase of Tilbury, Otia imperialia, Oxford Medieval Texts, Oxford 2002, 302. Por. też: A. Schulten, Iberische Landeskunde: Geographie des antiken Spanien, wyd. 2, Baden-Baden 1974, 12-22; H. García-Aráez, Los Mapamundis de los Beatos. Origen y características principales, „Miscelánea Medieval Murciana” 18 (1993-1994) 70; P. Kochanek, Iluzja schematów choro- i topograficznych jako baza mnemotechnicznej portolany w starożytności, w: Tworzenie iluzji spolecznej-wiedza w sferze publicznej, red. J. Szymczyk - M. Zemła - A. Jabłoński, Studia nad Wiedzą 5, Lublin 2012, 88; P. Kochanek, Wpływ starożytnej schematyzacji mnemotechnicznej na średniowieczna $i$ wczesno-nowożytna kartografię, „Vox Patrum” 38 (2018) t. 69, 318-320 oraz 319 , tab. XI/11.

13 Legendy z ,trójkąta” hiszpańskiego mapy Beatusa z Burgo de Osma budzą pewne kontrowersje: lekcja Corduba jest hipotezą Konrada Millera (Mappaemundi. Die ältesten Weltkarten, t. 1, s. 34). W ten sposób badacz niemiecki starał się odczytać mocno zatarty już wtedy termin; toponim Olisbona zdaniem Hermenegilda García-Aráeza (6 II 1918-11VII 2006 - Los mapamundis de los Beatos, cz. 2, s. 106) powinno się czytać Olisipona; termin Toletum z kolei K. Miller (Mappaemundi. Die ältesten Weltkarten, t. 1, s. 34) zastąpił pojęciem Toleto; nazwę Terracona natomiast H. García-Aráez (Los mapamundis de los Beatos, cz. 2, s. 108) odczytał jako Tarracona. Również kwestia odczytania nazw obu rzek nie jest jednoznaczna. K. Miller (Mappaemundi. Die ältesten Weltkarten, t. 1, s. 34) odczytał nazwę pierwszej z nich jako $F$. Tavus, co jest ewidentnym błędem. Właściwą lekcję, czyli F. Durius, podali Gonzalo Menéndez-Pidal (12 IV 1911-11 XII 2008 - Mozárabes y Asturianos, s. 258) oraz, idący za nim, H. García-Aráez (Los mapamundis de los Beatos, cz. 2, s. 102). Z kolei w odniesieniu do nazwy F. Minius K. Miller (Mappaemundi. Die ältesten Weltkarten, t. 1, s. 34) napisał: „F. (Ibe)ris oder F. (Bae)tis”. Identyfikacja ta jest niestety błędna. G. Menéndez-Pidal (Mozárabes y Asturianos, s. 258) a za nim H. García-Aráez (Los mapamundis de los Beatos, cz. 2, s. 106) podali lekcję $F$. 
latarni morskiej w La Coruña. Cytowany już Orozjusz tak opisuje tę latarnię: „Secundus angulus (Hispaniae) circium intendit; ubi Brigantia Gallaeciae ciuitas sita altissimam pharum et inter pauca memorandi operis ad speculam Britanniae erigit"14. Latarnię zbudowano najprawdopodobniej za panowania Trajana (98-117), około roku 110. Z kolei legenda odwołująca się do mitu o Heraklesie każe widzieć w owej latarni dzieło tego właśnie herosa, który tutaj miał pokonać Geriona i pod skałą, na której wzniósł latarnię dla upamiętnienia swego zwycięstwa, umieścił głowę zabitego przeciwnika ${ }^{15}$. Stąd późniejsza nazwa hiszpańska Torre de Hércules, która funkcjonuje do dziś, jako że latarnia ta jest jedyną latarnią antyczną pełniącą swą pierwotną funkcję również współcześnie. $Z$ tego też powodu zbudza duże zainteresowania badaczy antyku, stając się przedmiotem licznych studiów ${ }^{16}$.
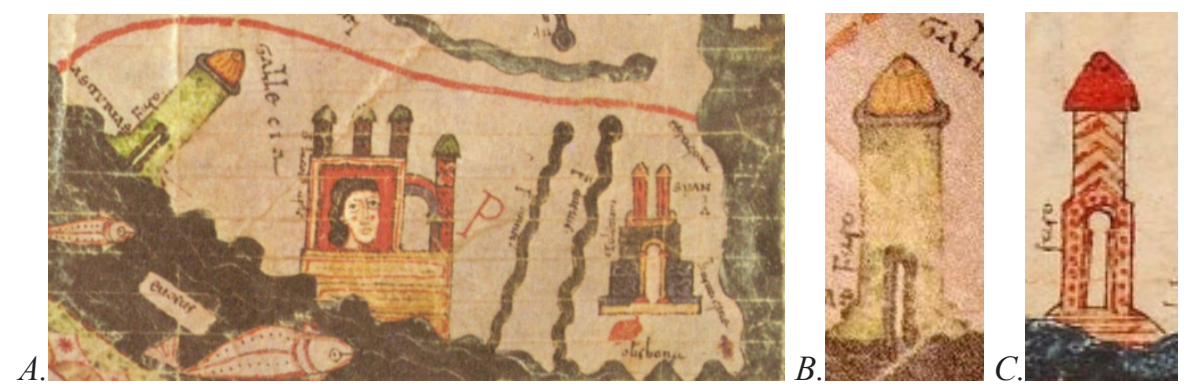

Fig. 2A-C: A. Hiszpania na mapie Beatusa z Burgo de Osma ${ }^{17}$; B. Latarnia morska w La Coruña ${ }^{18}$; C. Latarnia morska w Aleksandrii

Minei. Jednak właściwsza wydaje się niżej podpisanemu lekcja $F$. Minius będąca pełną łacińską nazwę rzeki Miño.

14 Orosius, Historia adversus paganos I 2, 69, CSEL 5, s. 27, 1-3 (= PL 31, 688B-689A).

15 Por. F.J. González García, Hércules contra Gerión. Mitos y legendas de la Torre de Hércules, t. 2, A Coruña 1998; F.J. González García, The Legendary Traditions about the Tower of Hercules (A Coruña, Spain), „Folklore” 125 (2014) nr 3, 306-321. Por. też: D. Barbarzak, Herkules i Gerion, królowie Hiszpanii. Mit i jego recepcja w iberyjskich kronikach doby średniowiecza i nowożytności, ,Symbolae Philologorum Posnaniensium Graecae et Latinae" 28 (2018) nr 2, 114.

16 Wiele cennych wskazówek bibliograficznych zawiera dwudziesty numer (z roku 2009) czasopisma „Brigantium”, który został poświęcony w całości właśnie tej latarni.

17 Źródło kopii: https://commons.wikimedia.org/wiki/File:WesternEurope BeatusOsma.jpg (dostęp: 11.01.2019). Por. Kochanek, ,,Rozestanie Apostołów” na mapie Beatusa z Burgo de Osma, s. 716, fig. 4.

18 Wycinek mapy Beatusa z Burgo de Osma, na którym to fragmencie jest latarnia z La Coruña, pojawia się w wielu opracowaniach. Por. S. Hutter, Der römische Leuchtturm von La Coruña, Madrider Beiträge 3, Mainz 1973, tab. 21/b; T. Hauschild, Der römischen Leuchtturm von La Coruña (Torre de Hercules). Probleme seiner Rekonstruktion, 
Porównanie latarni w La Coruña $\mathrm{z}$ latarnią w Aleksandrii (fig. 2BC) wskazuje, że obie budowle, choć podobne, nie są jednak identyczne. Różnią się bowiem wyraźnie zarówno kształtem, jak i kolorami. W kwestii kształtu zwracają uwagę dachy, drzwi wejściowe oraz same cylindryczne korpusy latarń: korpus latarni aleksandryjskiej wydaje się być dwupiętrowy, a wejście do niego przypomina wejście do „mihrabu”, niszy modlitewnej, która wskazywała jednocześnie „kiblę” - kierunek Mekki, nawiązując w ten sposób do charakterystycznej cechy budownictwa mauretańskiego ${ }^{19}$. Jeśli chodzi o kolory, to czerwień latarni egipskiej wyraźnie kontrastuje z zielenią korpusu latarni hiszpańskiej. Ów kolor nadziei przypisany latarni w La Coruña, usytuowanej na zachodnich kresach europejskiej, chrześcijańskiej części ekumeny tuż obok S. Jacobus, czyli Santiago de Compostela, pielgrzymkowego sanktuarium Jakuba Starszego, nie wydaje się być przypadkowy. Połączenie tych dwóch elementów, latarni i sanktuarium, oznacza położenie szczególnego akcentu na nadzieję (...) dotarcia do portu i to zarówno $\mathrm{w}$ sensie realnym, jak i przenośnym: dotarcia do szczęśliwej przystani po trudach żeglowania przez wzburzony ocean życia. Latarnia morska bowiem to rodzaj przewodnika, który prowadzi ludzi (morza) do miejsca przeznaczenia, dając im nadzieję pomyślnego zakończenia niebezpiecznej drogi ${ }^{20}$. W kulturze wczesnochrześcijańskiej, o czym niżej, latarnia morska oznaczała przybycie do portu ostatecznego przeznaczenia

\footnotetext{
„Madrider Mitteilungen” 17 (1976) 256, fig. 15; J. Martínez Maganto, Faros y luces de señalizacion en la navegacíon antiqua, „Cuadernos de Prehistoria y Arqueología” 17 (1990) 86, fig. 12; J.M. Bello Diéguez, La Edad Media: El recuerdo del Faro y el uso como Fortaleza, w: Ciudad y Torre. Roma y la Ilustración en La Coruña, La Coruña 1991, 180, fig. II-28(2); Bello Diéguez, La Torre despues de la Reforma, w: Ciudad y Torre, s. [203], fig. II-28(1); S. Hutter, El faro romano de la Coruña, tł. F. Urgorri Casado, w: S. Hutter - T. Hauschild, El faro romano de la Coruña, La Coruña 1991, [71], tab. 21/b; T. Hauschild, El faro romano de La Coruña (Torre de Hércules). Problemas de su reconstrucción, tł. M.L. Cortés, w: S. Hutter - T. Hauschild, El faro romano de la Coruña, La Coruña 1991, [110], fig. 22; B. Giardina, Navigare necesse est: Lighthouses from Antiquity to the Middle Ages, British Archaeological Reports. International Series 2096, Oxford 2010, 331, fig. 202; J.A. Sánchez-García, Desvelando un fantasma. Sobre un mapamundi árabe, la Torre de Hércules y las representaciones de faros en la cartografía medieval, „Memoria y Civilización" 20 (2017) 285, fig. 7.

19 Ściślej rzecz ujmując, wejście do latarni aleksandryjskiej przypomina bądź wejście do „mihrab” w Sali modlitw przy pałacu Aldżaferija (hiszp. Palacio de la Aljefería) w Saragossie, bądź wejście do tejże niszy w meczecie w Kordobie. Por. V. Chico Picaza - F. Massip Bonet, Historia sztuki świata, t. 2, tł. D. Bartnik - B. Gutowska-Nowak, Warszawa 1999, 169; J. Pijoan, Sztuka islamu, w: Sztuka świata, t. 4, tł. R. Kalicki - B. Ostrowska, Warszawa 1990, 204.

20 Por. T. Costa, To the Lighthouse: Sentinels at the Water's Edge, w: Art and Identity at the Water's Edge, red. T. Cusack, Farnham 2012, 88.
} 
po burzliwych i zmiennych kolejach życia, a zatem kres ziemskiej drogi ${ }^{21}$. Była więc dla chrześcijan de facto symbolem zbawienia ${ }^{22}$. W tym kontekście warto również przywołać fragment rozważań Mate Perišić’a: „In the Middle Ages, so called «church lights» served at lighthouses and sailing navigation and were maintained by monks. These lights were lit usually on church towers situated on the coast. There were dedicated mostly to St. Nicolas, a patron saint of sailors" 23 . Winiecie latarni morskiej z mapy Beatusa z Burgo de Osma warto przyjrzeć się pod tym właśnie kątem, ponieważ realnie istniejąca budowla przeniesiona na tę mapę wydaje się posiadać znacznie bogatszą i głębszą treść, która wychodzi daleko poza aspekt dekoracyjno-estetyczny. W tym celu należy odwołać się do symboliki latarni morskiej, analizując jej przedstawienia zarówno na pogańskich, jak i wczesnochrześcijańskich reliefach sarkofagów oraz na płytach grobowych pochodzących z katakumb rzymskich, które wyrażają ducha wiary pierwszych chrześcijan.

$$
* * *
$$

Jeśli chodzi o sarkofagi, to latarnia morska widnieje przynajmniej na kilku zachowanych monumentach tego typu, które pochodzą z epoki cesarstwa rzymskiego. Jednym z najbardziej znanych jest pogański sarkofag, datowany na przełom II i III wieku po Chrystusie, przedstawiający podróż

21 Por. M. Reddé, La représentation des phares à l'époque romain, „Mélanges de l'École Française de Rome. Antiquité" 91 (1979) z. 2, 863; M.-H. Quet, Pharus, „Mélanges de l'École Française de Rome. Antiquité” 96 (1984) z. 2, 812-813; Martínez Maganto, Faros y luces de señalizacion, s. 77.

22 Por. G.B. de Rossi, Escavazioni nel cimitero di Callisto, „Bullettino di Archeologia Cristiana" 6 (1868) z. 1, 11; M. Besnier, Pharus, w: Dictionnaire des Antiquités Grècques et Romaines, red. G. Daremberg - E. Saglio, t. IV/1, Paris 1873, 432; J.A. Martigny, Dictionnaire des antiquités chrétiennes, Paris 1877, 640; H. Marucchi, Éléments d'archéologie chrétienne. Notions générales, Paris - Rome 1899, 163; H. Marucchi, Handbuch der christlichen Archäologie, red. F. Segmüller, Einsiedeln - Waldshut - Cöln 1912, 218; H. Marucchi, Manuale di archeologia cristiana, red. G. Belvederi, wyd. 4, Roma 1933, 207; A. Grabar, Recherches sur les sources juives de l'art paléochrétien, cz. 2, „Cahiers Archéologiques" 12 (1962) 138; J. Poeschke, Leuchtturm, w: Lexikon der christlichen Ikonographie, t. 3, wyd. 2, Rom - Freiburg im Breisgau 1994, 92; E. Ehler, Figürliche Loculusplatten aus dem frühchristlichen Rom, t. 1, Marburg 2012, 100 (= https://archiv. ub.uni-marburg.de/diss/z2012/0956/pdf/dee.pdf (dostęp: 20.01.2019)); B. Giardina, Navigare necesse est: il faro tra mondo antico e medioevo, „Histria Antiqua” 21 (2012) 453. Por. też: Quet, Pharus, s. 813-814, przyp. 74.

23 M. Perišić, Lighthouses as a part of tourist offer being specific tourist destination, w: Interdisciplinary Management Research V. The J.J. Strossmayer University of Osijek, Faculty of Economics in Osijek, red. D. Barković, Osijek 2009, 382. 


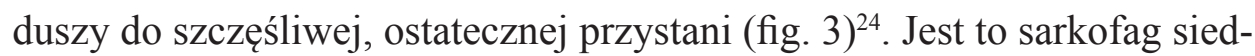
mioletniego chłopca o imieniu Iulius Filokyrios, jak to wynika z inskrypcji zamieszczonej na sarkofagu tuż pod jego podobizną: D - M \| IVLIO . FILOKYRIO \| FILIO - BENE - MERENTI \| DVLCISSIMO - Q

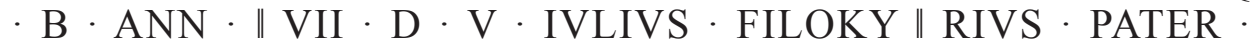
FECIT $^{25}$. Wydaje się, że istotę tego reliefu dobrze oddał Henri Leclercq (4 XII 1869-23 III 1945), pisząc, że owa płaskorzeźba

nous montre le voyage de l'âme figurée sous les traits de Psyché conduite par l'amour dans une barque suivie de deux autres barques qui se dirigent vers le port; la troisième barque offre le même sujet, mais ici est encore parmi les flots et elle témoigne son inquiétude et sa douleur tandis qu'à l'instant d'entrer dans le port elle se réjouit et joue de la trompe. [...]; à l'extrémité droite on voit un phare à trois étages sur une base pleine ${ }^{26}$.

W tym samym duchu można zinterpretować również relief drugiego sarkofagu (fig. 4) ${ }^{27}$, który jest rówieśnikiem monumentu Juliusza Filokyriosa. Z kolei na koniec III wieku po Chrystusie jest datowany tzw. sarkofag z Ny-Carlsberg Glyptothek (fig. 5) ${ }^{28}$. Tutaj na pokładzie trzech żaglowców (poniżej widoczny jest tylko jeden - najbliższy latarni morskiej) płynie kilka dusz (postacie te są nagie), których miotane

24 Sarkofag ten znajduje się obecnie w Rzymie (Palazzo Vaccari-Bacchettini, nr inw. 56).

25 Inskrypcja ta pojawia się w wielu opracowaniach. Por. D. Raoul-Rochette, Deuxième Mémoire sur les Antiquités chrétiennes des Catacombes: Pierres sépulcrales envisagées sous le double rapport des formules et des symboles funéraires, w: Mémoires de l'Institut Royal de France. Académie des Inscriptions et Belles-Lettres, vol. XIII/1, Paris 1837, 222-223; R. Lanciani, Ricerche topografiche sulla città di porto, „Annali dell'Istituto di Corrispondenza Archeologica" 40 (1868) 158; C.L. Visconti, Fronte di sarcofago con Tritoni, Nereidi e navi, ed altri funebri monumenti con rappresentanza di navi, „Bullettino della Commissione Archeologica Municipale” (1872-1873) 265; M. Collignon, Essai sur les monuments grecs et romains relatifs au mythe de Psyché, Bibliothèque des Écoles Françaises d'Athène et de Rome 2, Paris 1877, 434 (nr 187); F. Matz - F. von Duhn, Antike Bildwerke in Rom mit Ausschluss der grösseren Sammlungen, t. 2, Leipzig 1881, 219.

26 H. Leclercq, Phare, w: DACL, t. 14/1, Paris 1939, 671.

27 Określenie „Sarkofag «Garrucci»” powstało na użytek niniejszego artykułu, ponieważ wielu autorów powołuje się właśnie na przerys, który pochodzi z pracy Raffaele Garrucci'ego (22 I 1812-5 V 1885): Storia della arte cristiana nei primi otto secoli della Chiesa, t. 5, Prato 1879, tab. 395/10.

28 Sarkofag jest przechowywany w Kopenhadze (Ny-Carlsberg Glyptothek, nr inw. 1299). 
morskimi falami statki zbliżają się do latarni. Należy podkreślić, że wszystkie latarnie znajdują się po prawej stronie reliefu i obok solidnej podstawy posiadają trzy (fig. 3 i 5) lub cztery (fig. 4) kondygnacje. Taki sposób lokalizacji latarni wydaje się nie być dziełem przypadku. Przesunięta w prawo latarnia bowiem zostaje niejako siłą rzeczy usunięta w cień. Widz nie dostrzega jej od razu, lecz patrzy na statki i ich „załogi”. Nie cel zatem, czyli bezpieczny port, jest tutaj ważny, lecz wizja żeglugi ludzkiej duszy po niebezpiecznym morzu codziennego życia. To jej wybory zadecydują o tym, czy ostatecznie dopłynie do bezpiecznego portu. Można by wręcz powiedzieć, że takie ustawienie latarni zdradza silnie antropocentryczną mentalność osób, które zleciły wykonanie tego reliefu. Zmarginalizowana latarnia posiada jednak na szczycie wyraźnie zaznaczony płomień. Nie jest to więc martwa budowla, lecz emitująca światło przewodniczka drogi. Taka struktura reliefu wydaje się sugerować, że dusza ludzka, choć w swych wyborach jest autonomiczna, to jednak powinna ich dokonywać z myślą o porcie życiowego przeznaczenia. W ten sposób relief sepulkralny staje się obrazem określonej koncepcji etyczno-moralnej, a symbolika poszczególnych elementów nabiera charakteru dydaktycznego.
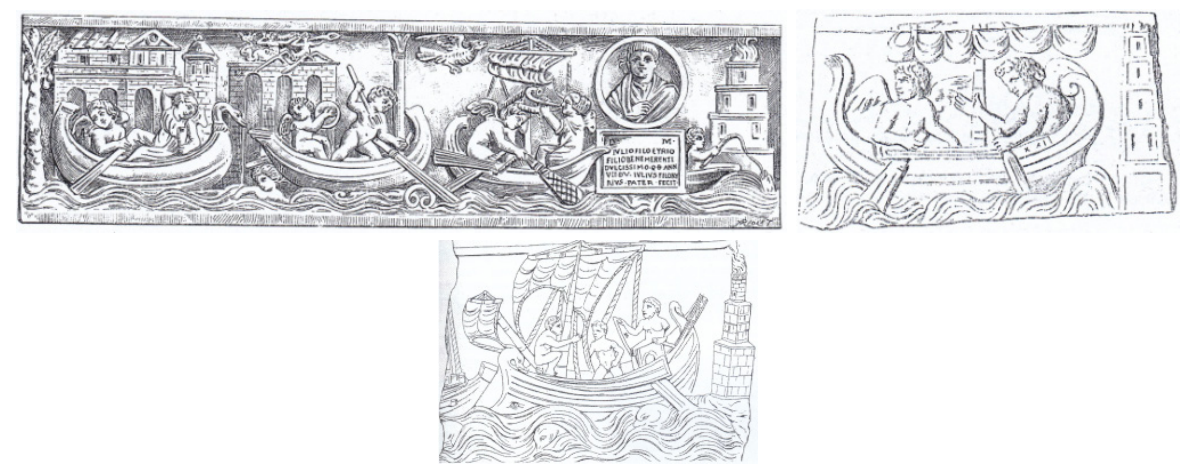

Fig. 3-5: Sarkofagi, których płaskorzeźby mają latarnię morską po prawej stronie (II-III wiek po Chrystusie).

Fig. 3: Sarkofag Juliusza Filokyriosa ${ }^{29}$;

29 Źródło przerysu: H. Leclercq, Ame, w: DACL, t. I/1, Paris 1907, 1477-1478, fig. 337. Por. Visconti, Fronte di sarcofago con Tritoni, tab. IV (między s. 268 a 269); J.J. Bachofen, Römische Grablampen nebst einigen andern Grabdenkmälern vorzugsweise einiger Sammlung. Tafelband, Basel 1890, tab. 46; R. Reitzenstein, Die Göttin Psyche in der hellenistischen und frühchristlichen Literatur, Sitzungsberichte der Heidelberger Akademie der Wissenschaften. Philosophisch-Historische Klasse 10, Heidelberg 1917, 
Fig. 4: Sarkofag „Garrucci”30;

Fig. 5: Sarkofag z Ny-Carlsberg ${ }^{31}$

Latarnia morska była też niekiedy umieszczana w środku reliefu, stanowiąc centralny punkt odniesienia płaskorzeźby, a jednocześnie koncentrując na sobie spojrzenie widza. Akcent został więc tutaj przeniesiony z metaforycznej żeglugi duszy na punkt docelowy jej życiowej podróży. Ów silnie wyakcentowany teleologizm wskazuje na inny typ mentalności zamawiającego ten rodzaj płaskorzeźby. Przykładem takiego przeniesienia akcentu może być fragment wieka sarkofagu z Neapolu (fig. 6) (2) $^{32}$ który powstał w II wieku po Chrystusie, oraz datowana na drugą połowę III wieku po Chrystusie wczesnochrześcijańska płyta grobowa z Katakumb Pretekstata (fig. 7) ${ }^{33}$. Ta ostatnia płaskorzeźba przedstawia dwa wyładowane towarem statki handlowe, pomiędzy którymi stoi trzypiętrowa latarnia morska z bardzo wyraźnie zaznaczonym płomieniem na szczycie. Statki są zwrócone rufami do latarni. Na każdym z nich widać po sześć amfor, ustawionych w dwóch rzędach, które wydają się szczelnie wypełniać jego ładownie. Nieco wolnej przestrzeni znajduje się tylko na rufie, w miejscu przeznaczonym dla sternika. Jednak wiosła sterowe są pozbawione obsługi. Na pokładzie nie ma bowiem żywej duszy. Statki te zostały więc załadowane ,po brzegi”, lecz wydają się czekać

tab. IIa; Ch. Picard, Sur quelques représentations nouvelles du phare d'Alexandrie et sur l'origine alexandrine des paysages portuaires, „Bulletin de Correspondance Hellénique” 76 (1952) 92, fig. 14; Reddé, La représentation des phares, s. 861, fig. 3; J.M. Noguera Celdrán, Instalaciones portuarias romanas: representaciones iconográficas y testimonio histórico, „Anales de Prehistoria y Arqueología” 11-12 (1995-1996) 233, fig. 19. Dalsza literatura na temat tego sarkofagu: https://arachne.uni-koeln.de/arachne/index.php?view [layout] $=$ objekt_item\&search[constraints][objekt][searchSeriennummer] $=608905$ (dostęp: 20.01.2019).

30 Źródło przerysu: Leclercq, Phare, szp. 671, fig. 10155. Por. H. Thiersch, Pharos: Antike, Islam und Occident. Ein Beitrag zur Architekturgeschichte, Leipzig - Berlin 1909, 16, fig. 13.

31 Źródło przerysu: L.A. Veitmeyer, Leuchtfeuer und Leuchtapparate, MünchenLeipzig 1900, 21, fig. 22. Por. Thiersch, Pharos, s. 17, fig. 16a-b; R. Amedick, Die Sarkophage mit Darstellungen aus dem Menschenleben, cz. 4, Die antiken Sarkophagreliefs I/4, Berlin 1991, tab. XLVII/1; Giardina, Navigare necesse est, s. 33, fig. 29; A. Lichtenberger, Glück und Gefahr - Ambivalente Meereserfahrung in der Bildwelt römischer Sarkophage, w: Das Mittelmeer und der Tod, red. A. Berner - J.-M. Henke - A. Lichtenberger - B. Morstadt - A. Riedel, Mittelmeerstudien 13, Paderborn 2016, 502, fig. 7.

32 Sarkofag ten jest przechowywany w Neapolu (Museo Archeologico Nazionale di Napoli, nr inw. 29147).

33 Zabytek ten jest przechowywany w Rzymie (Catacombe di Pretestato - Museo Cristiano, nr inw. 925). 
bądź na powrót załogi i opuszczenie portu, bądź na rozładunek. Niewątpliwie symbolika tego reliefu, opartego na zasadzie ścisłej symetrii, nasuwa wiele skojarzeń biblijnych. Zrezygnowano tutaj z metafory „wędrówki duszy”, kładąc akcent na morze, statki handlowe wypełnione w sumie dwunastoma amforami i na trzypiętrową latarnię morską o mocnym, a zatem widocznym z daleka, płomieniu, który rozświetla mroki (nocy), dając nadzieję szczęśliwego powrotu. Brak tylko tych, którzy są nosicielami tej nadziei. Ich nie ma już na statkach, a zatem i na morzu, ponieważ (...) odeszli, kończąc życiową podróż. Są po drugiej stronie nagrobnej płyty, gdzie ich nadzieja być może się spełniła. Jednak człowiek będący ,po tej strony” nie zna ich dalszego losu „po tamtej stronie”. Może jedynie życzyć im (i sobie) spełnienia nadziei. Relief ten wydaje się więc być swego rodzaju memento mori adresowanym przede wszystkim do tych, którzy jeszcze nie znaleźli się po jego drugiej stronie. To tu i teraz należy pamiętać, że jest strona prawa i lewa - jest zbawienie i potępienie ${ }^{34}$, dlatego też, być może, statki transportowe zostały ustawione symetrycznie po prawej i po lewej stronie latarni. Relief ten miał bez wątpienia skłaniać do refleksji, a jego dydaktyczno-katechetyczny wymiar wydaje się być oczywisty.
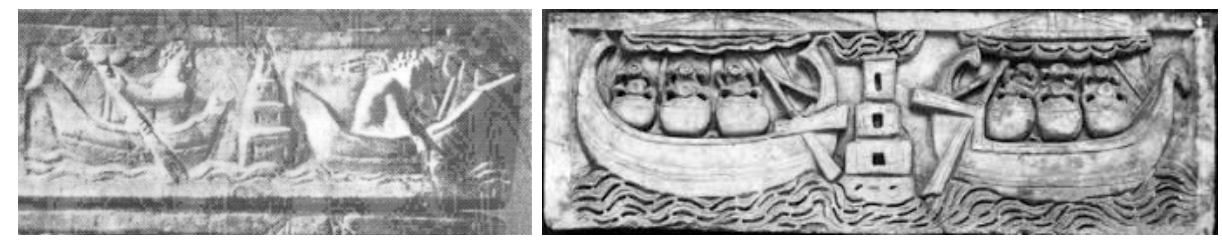

Fig. 6-7: Sarkofag i płyta grobowa, których płaskorzeźby mają latarnię morską na środku (II-III wiek po Chrystusie). Fig. 6: Wieko sarkofagu z Neapolu ${ }^{35}$; Fig. 7: Płyta grobowa z Katakumb Pretekstata ${ }^{36}$

34 Por. O. Nussbaum, Die Bewertung von rechts und links in der römischen Liturgie, JbAC 5 (1962) 158-171; U. Deitmaring, Die Bedeutung von rechts und links in theologischen und literarischen Texten bis um 1200, „Zeitschrift für Deutsches Altertum und Deutsche Literatur" 98 (1968) 265-292.

35 Źródło fotografii: https://arachne.uni-koeln.de/arachne/index.php?view[layout] $=$ objekt_item\&search [constraints][objekt][searchSeriennummer] $=608969$ (dostęp: 20.01.2019). Por. Amedick, Die Sarkophage mit Darstellungen aus dem Menschenleben, tab. $\mathrm{V} / 3$.

36 Źródło fotografii: https://arachne.uni-koeln.de/arachne/index.php?view[layout $]=$ objekt_item\&search $\quad[$ constraints] [objekt][searchSeriennummer] $=28859$ (dostęp: 20.01.2019). Por. Amedick, Die Sarkophage mit Darstellungen aus dem Menschenleben, tab. XLVII/3; Giardina, Navigare necesse est, s. 29, fig. 21; Lichtenberger, Glück und Gefahr, s. 503, fig. 11. 
Istnieją także na sarkofagach przedstawienia latarń morskich, które trudno jest interpretować w przedstawionej wyżej „dualistycznej” perspektywie prawej strony i centrum. Jednak w każdym przypadku latarnia morska sugeruje istnienie bezpiecznego portu, ku któremu należy zmierzać. Przykładem niech będą dwa sarkofagi, których datacja jest dyskusyjna. Powstały zapewne w okresie cesarstwa rzymskiego. Pierwszy z nich to marmurowy sarkofag z Palazzo Colonna w Rzymie (fig. 8). Na jego boku widnieje masywna, samotna latarnia morska. $Z$ jednej strony można ją odczytać jako symbol bezpiecznego portu. $Z$ drugiej zaś strony łatwo zauważyć, że na jej szczycie nie widać płomienia, co zdaje się symbolizować życie zgaszone bezpowrotnie przez śmierć. Atmosferę zadumy nad kruchością ludzkiej egzystencji wydaje się potęgować fakt, iż czteropiętrowa latarnia jest z kamieniarskiego punktu widzenia słabo dopracowana $^{37}$. Owa kamieniarska toporność pogłębia także wrażenie surowości majestatu śmierci. Więcej detali posiada tzw. „Sarkofag Nereid” (fig. 9) znajdujący się w Ogrodach Watykańskich, a ściślej w Casino di Pio IV. Tutaj dwupiętrowa latarnia, na szczycie której płonie ogień, jest flankowana przez dwie istoty: morskiego centaura $\mathrm{z}$ wiosłem $\mathrm{w}$ prawej ręce oraz delfina ${ }^{38}$.
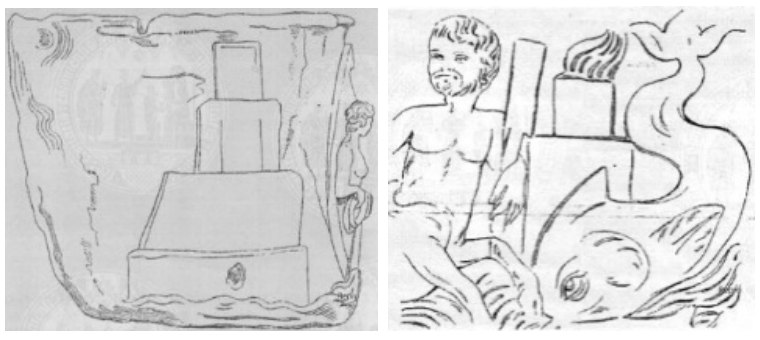

Fig. 8: Sarkofag z Palazzo Colonna ${ }^{39}$ Fig. 9: „Sarkofag Nereid”40

37 Por. G. Stuhlfauth, Der Leuchtturm von Ostia, „Mitteilungen des Deutschen Archaeologischen Instituts. Roemische Abteilung" 53 (1938) 149-150 (nr 6).

38 Por. Thiersch, Pharos, s. 17. Baldassarre Giardina (Navigare necesse est, s. 33) twierdzi, że jest to Posejdon trzymający wiosło.

39 Źródło przerysu: Giardina, Navigare necesse est, s. 306, tab. 77, fig. 152b. Por. E. Braun, Antike Marmorwerke. Erste und zweite Decade, Leipzig 1843, tab. X (Erste Decade); Thiersch, Pharos, s. 16, fig. 12. Por. też https://arachne.dainst.org/entity/3623938 (dostęp: 20.01.2019).

40 Źródło przerysu: Giardina, Navigare necesse est, s. 33, fig. 29. Por. Thiersch, Pharos, s. 17, fig. 15. Por. też: https://arachne.dainst.org/entity/3623933 (dostęp: 20.01.2019). 
Większość przedstawionych wyżej sarkofagów (fig. 3-6 i 8-9) to sarkofagi pogańskie. Chrześcijański charakter ma tylko płyta grobowa z Katakumb Pretekstata (fig. 7). Chrześcijaństwo przejęło de facto pewien gotowy i dobrze funkcjonujący schemat, gdzie morze (nieznane niebezpieczeństwo), statek (podróż po morskich bezdrożach) i latarnia morska (bezpieczny port) miały swą ugruntowaną symbolikę stanowiącą kulturowe bonum commune epoki. Przejęcie to nie było jednak bezkrytyczne, lecz twórcze. Przejęte formy wypełniono bowiem zupełnie inną treścią, czego dowodem jest chociażby wspomniany wyżej relief z Katakumb Pretekstata.

$$
* * *
$$

Latarnia morska $\mathrm{w}$ kontekście stricte chrześcijańskim pojawia się znacznie częściej na prostych marmurowych płytach, które zamykały nisze grobowe w katakumbach. Zwykle wyrytym tam latarniom morskim towarzyszą dodatkowe symbole oraz inskrypcje. Płyty te zdają się potwierdzać tezę, że latarnia morska była znanym symbolem funeralnym, jednak symbolu tego w okresie cesarstwa rzymskiego nie stosowano na szeroką skalę $^{41}$. Poniżej przedstawiono siedem przykładów płyt grobowych zaopatrzonych w latarnie morskie. Latarnie te znajdują się zwykle po prawej stronie płyty, co zdaje się korespondować ze sposobem ich lokalizacji na wskazanych wyżej sarkofagach (fig. 3-5). Jednak ze względu na znaczenie prawicy w Biblii i w liturgii chrześcijańskiej sens tego przesunięcia jest zupełnie inny niż na pogańskich reliefach sarkofagowych. Zgodnie z chrześcijańskim znaczeniem przypisywanym prawej stronie bowiem należy wnosić, że latarnia tam właśnie umieszczona symbolizowała zbawienie duszy $^{42}$. Nadzieję tę wyrażali ci, którzy pozostali po zewnętrznej stronie niszy grobowej.

Pierwszy przykład to płyta grobowa (fig. 10), datowana na III-IV wiek po Chrystusie, a pochodząca z Katakumb Cyriaka przy via Tiburtina, która jest aktualnie przechowywana w Muzeach Watykańskich (Lapidario Cristiano ex Lateranense, 15, nr inw. 32577). Jest to płyta marmurowa (12,5 x $48 \mathrm{~cm}$ ), na której są widoczne trzy elementy: (po lewej) statek handlowy ze zwiniętym żaglem i wiosłami sterowymi na rufie; (w centrum) czteropiętrowa latarnia morska, na szczycie której płonie ogień; (po prawej) fragment wyrazu - DIOR (... $)^{43}$. Drugi zabytek (fig. 11), datowany na IV wiek po Chrystusie, pochodzi z Katakumb św. Kaliksta przy via Appia Antica

41 Por. Ehler, Figürliche Loculusplatten aus dem frühchristlichen Rom, t. 1, s. 98.

42 Por. przyp. 34.

43 Powyższy opis płyty nagrobnej pochodzi z: E. Ehler, Figürliche Loculusplatten aus dem frühchristlichen Rom, t. 2, Marburg 2012, 685 (XI 4.13) (= https://archiv.ub.uni-marburg.de/diss/z2012/0956/pdf/ def.pdf (dostęp: 20.01.2019)). Opis tego zabytku 
i dziś również jest przechowywany w Muzeach Watykańskich (Lapidario Cristiano ex Lateranense, 15, nr inw. 32586 - odlew). Ten fragment marmuru $(21 \times 38 \mathrm{~cm})^{44}$ posiada zlokalizowaną w centrum trzypiętrową latarnię morską z wyraźnie zaznaczonym płomieniem na szczycie oraz wpisaną w jej wnętrze sekwencją greckich liter. Ich analizy dokonał w roku 1868 Giovanni Battista de Rossi (23 II 1822-20 IX 1894), dochodząc do następującego wniosku:

Per quanto io le abbia in molti modi diversi composte ed ordinate, ne ho trovato sempre una sola lezione possibile AOPATA, che significa invisibilia. [...] Laonde l'epigrafe AOPATA è dichiarazione del faro e del porto invisibili all'occhio carnale, e visibile a quello della fede. Ma è degno di speciale osservazione, che le predette lettere sono aggruppate in guisa da formare coi tre A e col P il monogramma (di Cristo) ${ }^{45}$.

Tezę tę przejęła cała plejada znanych badaczy, m.in. Joseph-Alexandre Martigny (22 IV 1808-19 VIII 1880) ${ }^{46}$, Franz X. Kraus (18 IX 1849-28

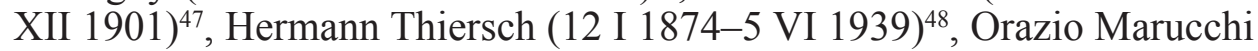
(10 XI 1852-21 I 1931) ${ }^{49}$, Georg Stuhlfauth (6 III 1870-2 II 1942) $)^{50}$ i Henri Leclercq ${ }^{51}$. Za ich autorytetem poszła również Elisabeth Ehler ${ }^{52}$. O. Marucchi uczynił nawet krok dalej, sugerując, że połączenie latarni morskiej i chrystogramu jest w gruncie rzeczy aluzją do tekstu Ewangelii św. Jana (J 12,8): „Ja jestem światłością świata”53.

z czasów, gdy był on przechowywany w Museo Cristiano Lateranense, znajduje się w: Stuhlfauth, Der Leuchtturm von Ostia, s. 151-152 (nr 9).

44 Sygnatura muzealna i wymiary płyty za: Ehler, Figürliche Loculusplatten, s. 684 (XI 4.8).
45 Rossi, Escavazioni nel cimitero di Callisto, s. 11.
46 Martigny, Dictionnaire des antiquités chrétiennes, s. 478.
47 F.X. Kraus, Geschichte der christlichen Kunst, Freiburg im Breisgau 1896, 125.
48 Thiersch, Pharos, s. 18.
49 O. Marucchi, Il recente scavo sotto il monastero die Trapisti, RivAC 4 (1927) z. $1-2,108$.

50 Stuhlfauth, Der Leuchtturm von Ostia, s. 154, przyp. 2.

51 Leclercq, Phare, szp. 673.

52 Ehler, Figürliche Loculusplatten, s. 684 (XI 4.8). Autorka podaje także inny sposób odczytania powyższej sekwencji liter, a mianowicie jako ADIODATA, powołując się na Epigraphic Database Bari. Inscriptions by Christians in Rome (3rd-8th cent. CE) (www.edb.uniba.it/epigraphy/3531 (dostęp: 30.01.2019). Jednak teza G.B. de Rossiego wydaje się o wiele bardziej przekonująca.

53 Marucchi, Il recente scavo sotto il monastero die Trapisti, s. 108-109. 

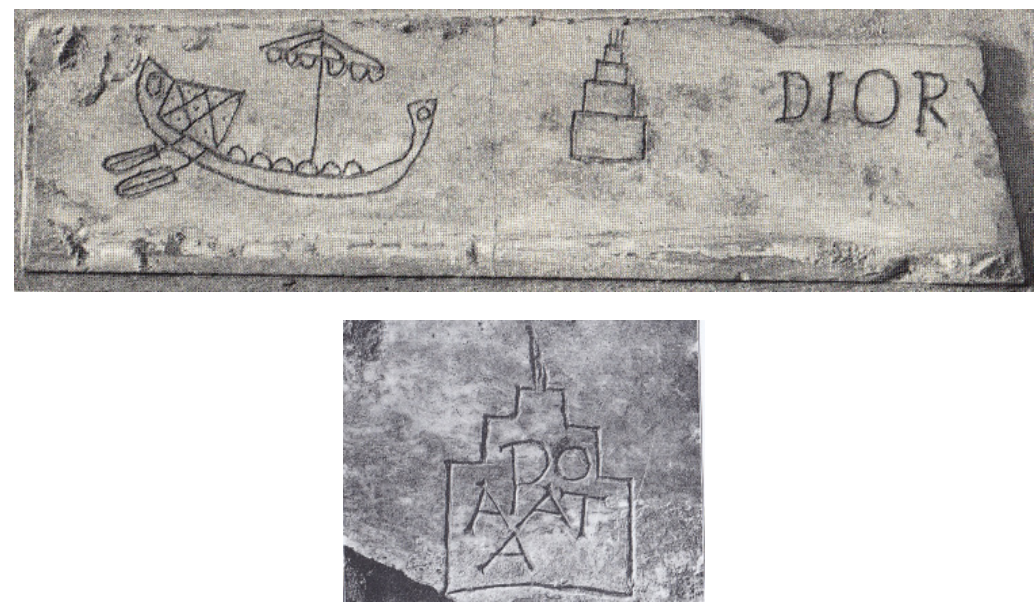

Fig. 10: Płyta z Katakumb Cyriaca (Catacombe di Ciriaco $=$ di San Lorenzo) ${ }^{54}$ Fig. 11:

Płyta z Katakumb św. Kaliksta (Catacombe di San Callisto) ${ }^{55}$

Trzecia płyta (fig. 12A-B), która została prawdopodobnie wykonana w IV wieku po Chrystusie, była częścią nagrobka z Coemeterium in vinea Eustachiorum przy via Latina. Obecnie zaś jest przechowywana w Muzeach Watykańskich (Lapidario Cristiano ex Lateranense, 15, nr inw. 28598). Marmurowa płyta ma $29 \mathrm{~cm}$ wysokości i $80 \mathrm{~cm}$ długości ${ }^{56}$, jest dedykowana Firmii Wiktorii, która zmarła w wieku 65 lat:

54 Źródło fotografii: Stuhlfauth, Der Leuchtturm von Ostia, s. 153, fig. 5. Por. L. Perret, Catacombes de Rome, t. 5, Paris 1851, tab. XLI/10; T. Roller, Catacombes de Rome. Histoire de l'art et des croyances religieuses pendant les premiers siècles du christianisme, t. 1, Paris 1881, tab. XI/62; O. Marucchi, I monumenti del Museo Cristiano Pio-Lateranense, Milano 1910, tab. LVIII/62; G. Stuhlfauth, Das Schiff als Symbol der altchristlichen Kunst, RivAC 19 (1942) 116 (13) - tutaj jest tylko inskrypcja (brak przerysu); Giardina, Navigare necesse est, s. 308, tab. 79, fig. 156c; Ehler, Figürliche Loculusplatten, t. 2, s. 685 (XI 4.13).

55 Źródło fotografii: Marucchi, Il recente scavo sotto il monastero die Trapisti, s. 109, fig. 1. Por. Rossi, Escavazioni nel cimitero di Callisto, s. 12, fig. 2; Martigny, Dictionnaire des antiquités chrétiennes, s. 478; Marucchi, I monumenti del Museo Cristiano Pio-Lateranense, tab. LXXX/240; Leclercq, Phare, szp. 672, fig. 10157; P. Saint-Roch, Le cimitière de Basileus ou Coemeterium sanctorum Marci et Marcelliani Damasique, Roma Sotterranea Cristiana 11, Città del Vaticano 1999, 92, fig. 34; Ehler, Figürliche Loculusplatten, z. 2, s. 684 (XI 4.8).

56 Dana techniczne za: Ehler, Figürliche Loculusplatten, s. 687 (XI 4.19). Opis tego zabytku z czasów, gdy był on przechowywany w Museo Cristiano Lateranense znajduje się w: Stuhlfauth, Der Leuchtturm von Ostia, s. 152 (nr 10). 
FIRMIA·VICTORA·QUE·VIXIT·ANNIS·LXV. Płyta ta składa się z trzech elementów: inskrypcji poświęconej zmarłej, czteropiętrowej latarni morskiej z płomieniem na szczycie, którą zlokalizowano w centrum, oraz z bezzałogowego żaglowca po lewej stronie latarni. Powierzchnia po jej prawej stronie jest pusta (fig. 12B), co może sugerować, że płyta ta nie została wykonana zgodnie z pierwotnym zamysłem lub też, że z jakichś powodów jej nie dokończono.

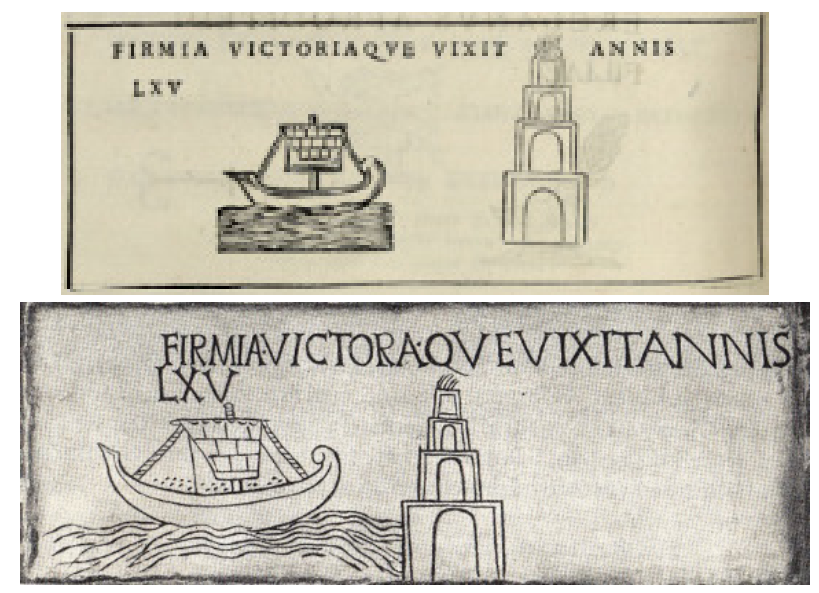

Fig. 12A-B: Płyta z Coemeterium in vinea Eustachiorum przy via Latina.

Fig. 12A: Przerys Marco A. Boldettiego ${ }^{57}$; Fig. 12B: Przerys Louis Perret'a ${ }^{58}$.

57 Marco A. Boldetti (19 XI 1663-4 XII 1749) dokonał nie tyle przerysu rzeczonej płyty grobowej, co jej graficznej interpretacji: M.A. Boldetti, Osservazioni sopra i cimiteri de' santi martiri, ed antichi Cristiani di Roma, Lib. 1, Roma 1720, 372. Przerys ten powtórzył Tommaso M. Mamachi (4 XII 1713-7 VI 1792): T.M. Mamachi, Originum et antiquitatum christianorum libri $X X$, t. 3, Romae 1751, 94, tab. 14/[2]. Pojawia się ona również w późniejszych opracowaniach. Por. Martigny, Dictionnaire des antiquités chrétiennes, s. 640 (autor ten wykorzystał tylko schemat latarni morskiej); Ehler, Figürliche Loculusplatten, s. 687 (XI 4.19). Źródło przerysu: Boldetti, Osservazioni sopra i cimiteri, s. 372.

58 Bodajże Louis Perret (1802-15 I 1882) dokonał jako pierwszy przerysu, który był wierną kopią oryginału: L. Perret, Catacombes de Rome, t. 5, Paris 1851, tab. LXXI/9. Za nim zaś poszli inni. Por. R. Garrucci, Storia della arte cristiana nei primi otto secoli della Chiesa, t. 6, Prato 1880, tab. 486/20; Roller, Catacombes de Rome, t. 1, tab. XI/63; Marucchi, Éléments d'archéologie chrétienne. Notions générales, s. 164; Thiersch, Pharos, s. 18, fig. 18; Marucchi, I monumenti del Museo Cristiano Pio-Lateranense, tab. LVIII/63; O. Marucchi, Epigrafia cristiana. Trattato elementare con una silloge di antiche iscrizioni cristiane principalmente di Roma, Milano 1910, tab. III/5; O. Marucchi, 
Dwie następne marmurowe płyty grobowe, których datacja jest bardzo niepewna, odnoszą się do zmarłych kobiet. Pierwszą z nich (fig. 13), pochodzącą z Coemeterium Pontiani, opublikował po raz pierwszy Raphael Fabretti (1618-7 I 1700) ${ }^{59}$. Płyta ta ma wymiary $29 \times 70 \mathrm{~cm}^{60}$, a treść jej inskrypcji najlepiej czytać, rozpoczynając od ostatniego wersu: FELIX · FECIT - HORIAE - QUAE - ANNOS $\|$ VI(XI)T - XX · MESIS · VI · DIAES $\cdot$ XVIII $\|$ BENE $\cdot$ MERENTI $\cdot$ IN $\cdot$ PACE. Chodzi prawdopodobnie o męża, Feliksa, który dedykuje tę inskrypcję swej młodo zmarłej żonie o imieniu Horia. Towarzyszą jej trzy rysunki: wieniec, czteropiętrowa latarnia bez ognia na szczycie oraz palmowa gałązka. Wieniec i palma mogą sugerować śmierć męczeńską. Latarnia natomiast odnosi się do portu zbawienia, który Horia, w co wierzy Feliks, osiągnęła. Stąd nie przypadkiem latarnia została umieszczona w centrum, pomiędzy wieńcem a gałązką palmową. Z kolei pochodzenie drugiej płyty (fig. 14) jest nieznane. Dziś znajduje się ona w rzymskim Museo Nazionale Romano. Płyta ta o wymiarach $35 \times 95 \mathrm{~cm}^{61}$ jest, jak widać, uszkodzona. Po jej prawej stronie znajduje się czteropiętrowa latarnia morska, na szczycie której płonie ogień. Resztę płyty natomiast zajmuje niepełna inskrypcja: (...)US · AUGURINUS · LOLIE $\|(\ldots)$ ETI · CO(N)IUGI - DULCIS $\|(B E N) E \cdot$ MERENTI · (IN · PA)CE. W tym przypadku nie ma wątpliwości, że chodzi o zmarłą żonę, niejaką Lolię, której mąż, Augurinus, poświęcił owo krótkie epitafium.

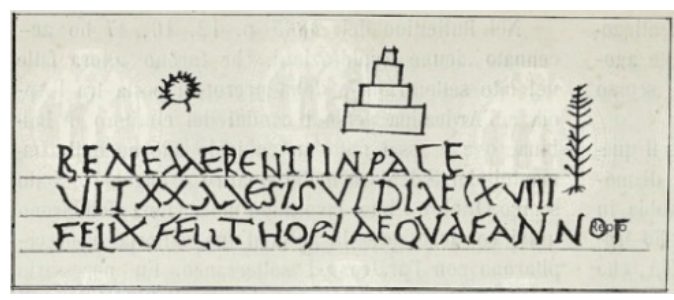

Handbuch der christlichen Archäologie, s. 218, fig. 65; C.M. Kaufmann, Handbuch der altchristlichen Epigraphik, Freiburg im Breisgau 1917, 54, fig. 52; H. Leclercq, Gordien et Épimaque, w: DACL, t. VI/1, Paris 1925, 1379, fig. 5329; Marucchi, Manuele di archeologia cristiana, s. 208; Stuhlfauth, Das Schiff als Symbol, s. 114 (4) - tutaj jest tylko inskrypcja (brak przerysu); Temi di iconografia paleocristiana, red. F. Bisconti, Sussidi allo Studio delle Antichità Cristiane XIII, Città del Vaticano 2000, tab. XXIIa; Ehler, Figürliche Loculusplatten, s. 687 (XI 4.19). Źródło fotografii (fig. 12B): Stuhlfauth, Der Leuchtturm von Ostia, s. 153, fig. 6.

59 R. Fabretti, Inscriptivm antiqvorvm quae in aedibvs paternis asservantur explicatio et additamentvm, Romae 1699, 566, fig. XLII.

60 Dane techniczne za: Ehler, Figürliche Loculusplatten, s. 693 (XI 4.67).

61 Dane techniczne za: Ehler, Figürliche Loculusplatten, s. 693 (XI 4.73). 


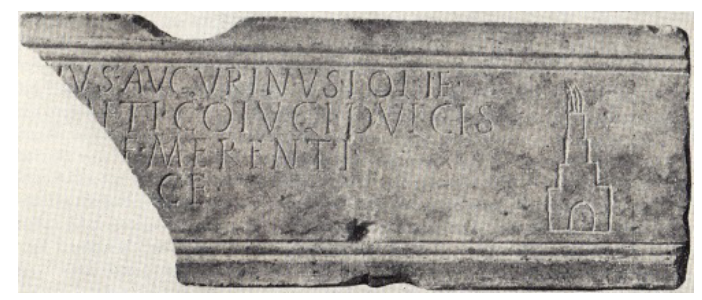

Fig. 13: Płyta z Coemeterium Pontiani (via Portuense) ${ }^{62}$ Fig. 14: Płyta grobowa Lolii ${ }^{63}$

Z kolei ciekawy element dekoracyjny w postaci dwóch latarń morskich posiada płyta grobowa, która dziś znajduje się Museo della Basilica di San Paolo fuori le mura (fig. 15). Jest ona datowana na V wiek po Chrystusie, a wymiary zachowanego fragmentu to $30 \times 52 \mathrm{~cm}^{64}$. Obie czteropiętrowe latarnie morskie, a w szczególności ta położona bardziej centralnie, przypominają latarnię z epitafium Firmii Wiktorii (fig. 12B) ${ }^{65}$. Ponadto latarnia ta posiada na swym najwyższym piętrze dodatkową linię, którą G. Stuhlfauth wyjaśnia w sposób następujący: „Das oberste Geschoß scheint durch eine Querlinie halbiert, der kleine Ring, der oben aufsitzt, soll vielleicht andeuten wollen, daß dieses Geschoß Rundform hat" ${ }^{\prime \prime}$. Na szczycie każdej z nich płonie ogień. Sama inskrypcja jest mocno uszkodzona ze wszystkich czterech stron, stąd jej właściwe odczytanie jest praktycznie niemożliwe: (...) BII (...) VOVVO $\|(\ldots)$ BIBA $\|$ (...) SE $\|(\ldots)$ A PARA $\|(\ldots) \mathrm{N}$ $(\ldots)^{67}$. Być może dwie latarnie wskazują na to, że chodzi o zmarłą kobietę, która była $\mathrm{w}$ ciąży, lub też o matkę, która zmarła w połogu wraz z noworodkiem. O tej rodzinnej tragedii mógł mówić ów nieczytelny dziś napis. Druga z kolei płyta (fig. 16), dziś zaginiona, zamykała loculus dziewczynki o imieniu Ursula. Dekoracja płyty ma dwa poziomy: górny i dolny. Poziom górny stanowi inskrypcja VRSULA DVLCISSIMA rozdzielona palmową gałązką. Po prawej stronie napisu widnieje chrystogram. Drugi, niższy poziom to cztery ustawione szeregowo przedmioty. Po prawej stronie

62 Źródło przerysu: https://arachne.dainst.org/entity/3623950 (dostęp: 5.01.2019). Por. Rossi, Escavazioni nel cimitero di Callisto, s. 12, fig. 1; Leclercq, Phare, szp. 671, fig. 10156. Por. też przyp. 59.

63 Źródło fotografii: Stuhlfauth, Der Leuchtturm von Ostia, s. 153, fig. 7. Por. Giardina, Navigare necesse est, s. 308, tab. 79, fig. 156b.

64 Dane techniczne za: Ehler, Figürliche Loculusplatten, s. 685 (XI 4.9).

65 Por. Stuhlfauth, Der Leuchtturm von Ostia, s. 154 (nr 14).

66 Stuhlfauth, Der Leuchtturm von Ostia, s. 154 (nr 14).

${ }^{67}$ Jeśli chodzi o próby odtworzenia napisu, por. Stuhlfauth, Der Leuchtturm von Ostia, s. 154, przyp. 1; Ehler, Figürliche Loculusplatten, s. 685 (XI 4.9). 
niemal pod chrystogramem widnieje czteropiętrowa latarnia morska, którą wieńczy wyraźnie zaznaczony duży płomień. Obok umieszczono portret zmarłej dziewczynki, a za nim ptaka z gałązką w dziobie oraz dzban z dużym uchem.

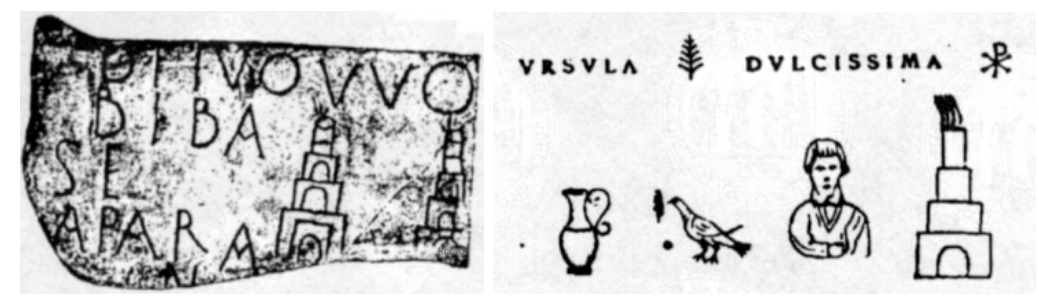

Fig. 15: Płyta z Coemeterium przy via Ostiense ${ }^{68}$ Fig. 16: Płyta VRSULA DVLCISSIMA (dziś zaginiona) ${ }^{69}$

Na siedmiu przywołanych wyżej płytach grobowych z latarniami morskimi znajduje się w sumie 8 takich obiektów (fig. 15 posiada 2 latarnie). Trzy spośród nich znajdują się z prawej strony reliefu (fig. 14-16). Pięć pozostałych natomiast umieszczono zdecydowanie w centrum (fig. 1015[bis]). Należy dodać, że skromny katalog latarń morskich widniejących na płytach nagrobnych jest nieco szerszy. Elisabeth Ehler, której praca podaje dziś bodajże najobszerniejszą listę w tym zakresie, przytacza w sumie 11 tego typu obiektów ${ }^{70}$. Warto również zauważyć, że latarnie na przedstawionych wyżej płytach mają zwykle cztery piętra. Czy jest to aluzja do czterech Ewangelii, których przekaz jest dla chrześcijanina najważniejszym drogowskazem do portu zbawienia?

$$
* * *
$$

Latarnia morska z La Coruña widnieje na niewielu zachowanych mapach średniowiecznych. Obok mapy Beatusa z Burgo de Osma (tab.

68 Źródło fotografii: https://arachne.dainst.org/entity/3623953 (dostęp: 5.01.2019).

69 Źródło przerysu: https://arachne.dainst.org/entity/3623949 (dostęp: 5.01.2019). Por. Leclercq, Phare, szp. 672, fig. 10158.

70 Do przedstawionych w tekście artykułu należy dodać jeszcze cztery. Por. Ehler, Figürliche Loculusplatten, s. 692 (XI 4.58; XI 4.59; XI 4.61; XI 4.66). Wiele cennych informacji w tym zakresie dostarczają także dwie inne prace: Stuhlfauth, Der Leuchtturm von Ostia, s. 142-154; F. Bisconti, Mestieri nelle catacombe romane. Appunti sul declino dell'iconografia del reale nei cimiteri cristiani di Roma, Studi e Ricerche 2, Città del Vaticano 2000. Jednak u podstaw wszystkich tych opracowań leży wielotomowa seria Inscriptiones christianae urbis Romae septimo saecolo antiquiores, czyli ICUR, którą w roku 1861 zainicjował Giovanni Battista de Rossi. 
I/1) znajduje się ona jeszcze na bodajże pięciu innych mapach z tego okresu. Chronologicznie najbliższa mapie Beatusa jest sporządzona między rokiem 1112 a 1115 tzw. mapa Europy Lamberta z Saint-Omer $(\text { tab. I/2 })^{71}$. Jednak latarnia jest tutaj zaledwie naszkicowana $\mathrm{w}$ formie wysokiej wieży-kolumny stojącej nad samym brzegiem oceanu, a na jej szczycie nie płonie ogień ${ }^{72}$. Przylega do niej inna, niższa i trudna do identyfikacji budowla. Obok zaś umieszczono nazwę prowincji: Galitia (hiszp. 'Galicia'). Kolejna winieta, która znajduje się na tzw. mapie z Sawley (tab. I/3) ${ }^{73}$, datowanej w szerokim przedziale lat 11101180, ma pewne cechy winiety kompozytowej, czyli swego rodzaju kolażu niejednorodnych elementów architektonicznych. Jest ona także nieco oddalona od brzegu. Przedmiotowa winieta została zorientowana wzdłuż osi północ-południe i składa się z dwóch części: po stronie północnej jest to wysoka, okrągła wieża zakończona stożkowatym dachem z kulą na szczycie; do wieży tej od południa przylega znacznie niższy od niej budynek z dwuspadowym, jak się wydaje, dachem, zwieńczonym krzyżem. Wieża została podzielona na trzy sekcje/piętra trzema parami równoległych linii. Dodatkowym elementem jest termin Galicia, czyli nazwa prowincji, w której wzniesiono zarówno latarnię

71 Mapa Europy Lamberta z Saint-Omer z „Liber Floridus”. Źródło oryginału: Gandawa, Universiteitsbibliotheek (data powstania: 1112-1115; wielkość oryginału: 207 x $175 \mathrm{~mm}$ ). Tekst legend mapy: K. Miller, Mappaemundi. Die ältesten Weltkarten, t. 3, Stuttgart 1895, 47-51; D. Lecoq, La Mappemonde de „Liber Floridus” ou la Vision du Monde de Lambert de Saint-Omer, „Imago Mundi” 39 (1987) 29, fig. 2. Fragmenty tekstu legend mapy: Chekin, Northern Eurasia in Medieval Cartography, s. 192 (XIII 6). Źródło kopii: A.-D. von den Brincken, Studien zur Universalkartographie des Mittelalters, red. T. Szabó, Veröffentlichungen des Max-Planck-Instituts für Geschichte 229, Göttingen 2008, tab. 20. Por. Chekin, Northern Eurasia in Medieval Cartography, s. 490 (XIII 6).

72 Por. Hutter, Der römische Leuchtturm von La Coruña, s. 17: „Die Darstellung bringt keinen Zusammenhang mit dem Turme des Herkules”. Por. też : Hutter, El faro romano de la Coruña, s. 32.

73 Mapa z Sawley (dawniej: Mapa Henryka z Moguncji). Źródło oryginału: Cambridge, Corpus Christi College, Ms 66, p. 2 (data powstania: 1110-1180; wielkość oryginału: 295 x 205 mm). Tekst legend mapy: Miller, Mappaemundi. Die ältesten Weltkarten, t. 3, s. 23-28; D. Lecoq, La mappemonde d'Henri de Mayence ou l'image du monde au XII siècle, w: Iconographie médiévale. Image, texte, contexte, red. G. Duchet-Suchaux, Paris 1990, 162-163. Fragmenty tekstu legend mapy: A.-D. von den Brincken, Fines Terrae. Die Enden der Erde und der vierte Kontinent auf mittelalterlichen Weltkarten, Monumenta Germaniae Historica. Schriften 36, Hannover 1992, s. 152 (24); Chekin, Northern Eurasia in Medieval Cartography, s. 139 (X 7). Źródło kopii: F. Reichert, Das Bild der Welt im Mittelalter, Darmstadt 2013, 32, fig. 2. Por. J. Brotton, Stynne mapy, red. L. Szaniawska, Warszawa 2016, 51. 
morską, jak i sanktuarium Jakuba Starszego. Taka struktura winiety sugeruje, że jej rysownik połączył dwie odrębne rzeczywistości: latarnię morską w La Coruña oraz sanktuarium św. Jakuba Apostoła w Santiago de Compostela ${ }^{74}$. Zachował przy tym właściwą orientację geograficzną, ponieważ latarnia znajduje się faktycznie na północnym wybrzeżu tej prowincji, Compostela zaś jest położona dokładnie na południe od La Coruña. W ten sposób to, co na mapie Beatusa z Burgo de Osma stanowiło dwie odrębne struktury graficzne (fig. 2A), zlało się w wyobraźni znacznie oddalonego od północnej Hiszpanii rysownika mapy z Sawley w jedną całość. Efektem tego graficznego zespolenia dwóch tak różnych elementów jest zatarcie pierwotnej funkcji wieży-latarni i narzucenie jej roli wieży-dzwonnicy, co każdy przeciętny lektor mapy z Sawley przyjmował i przyjmuje za dobrą monetę. Następną mapą w niniejszym zestawieniu jest wykonana około roku 1260 mapa z Psałterza Londyńskiego (tab. I/4) ${ }^{75}$. Znajduje się na niej wspomniana już wyżej nazwa prowincji (Galicia), a nad samym brzegiem oceanu wznosi się niewysoka, bezimienna wieża. Budowla ta jednak ze względu na małą średnicę samej mapy $(90 \mathrm{~mm})$ sprawia duże trudności interpretacyjne. Tylko na podstawie jej położenia oraz nazwy prowincji można hipotetycznie założyć, że winieta ta odnosi się do latarni morskiej. Z kolei datowana aktualnie na koniec XIII wieku mappamundi z Ebstorf (tab. $\mathrm{I} / 5)^{76}$ posiada winietę Brigantia $c[$ ivitas] (La Coruña). Winieta ta nie

74 Podobna sugestia znajduje się już w pracy Siegfrieda Huttera Der römische Leuchtturm von La Coruña (s. 17). Por. S. Hutter, El faro romano de la Coruña, s. 31.

75 Mapa z Psałterza Londyńskiego. Źródło oryginału: Londyn, British Library, Ms Add. 28681, fol. $9^{\text {r }}$ (data powstania: ok. 1260; średnica oryginału: $90 \mathrm{~mm}$ ). Tekst legend mapy: W.L. Bevan - H.W. Phillott, Mediaeval Geography: An Essays in Illustration of the Hereford Mappa Mundi, London 1873, XLI-XLIV; Miller, Mappaemundi. Die ältesten Weltkarten, t. 3, s. 38-42. Fragmenty tekstu legend mapy: Brincken, Fines Terrae, s. 155 (32); Chekin, Northern Eurasia in Medieval Cartography, s. 141-142 (X 9.1). Źródło kopii: Chekin, Northern Eurasia in Medieval Cartography, s. 455 (X 9.1).

76 Mapa z Ebstorf. Źródło oryginału: Mapa ta spłonęła w nocy z 8 na 9 października w Hauptstaatsarchiv w Hanowerze podczas bomdardowania miasta (data powstania: ok. 1300; wielkość oryginału: 3580 x 3560 mm). Tekst legend mapy: E. Sommerbrodt, Die Ebstorfer Weltkarte, [cz. Text], Hannover 1891; K. Miller, Mappaemundi. Die ältesten Weltkarten, t. 5, Stuttgart 1896; Die Ebstorfer Weltkarte. Kommentierte Neuausgabe in zwei Bänden, t. I/2, red. H. Kugler - S. Glauch - A. Willing, Berlin 2007. Fragmenty tekstu legend mapy: I. Hallberg, L'Extrème Orient dans la littérature et la cartographie de l'Occident des XIII,$X I V^{\mathrm{e}}$ et $X V^{\mathrm{e}}$ siècles. Études sur l'histoire de la géographie, Göteborg 1906 (nazwy geograficzne w porządku alfabetycznym); Среднеьковье въ его памятникахъ: сборникъ переводовъ, red. Д.Н. Егорова, Москва 1913, 276289; Destombes, Mappemondes A.D. 1200-1500, s. 195-196 (52, 2); Chekin, Northern 
styka się jednak bezpośrednio z linią brzegową, podobnie jak to jest na mapie z Sawley. Składa się natomiast z trzech elementów: muru obronnego, niewysokiej wieży bramnej zaopatrzonej w stożkowaty dach zakończony kulą oraz drugiej, wyższej wieży, która wystaje ponad fortyfikacje miasta. Wieża ta nie posiada co prawda jednoznacznych cech latarni morskiej (np. płonącego na jej szczycie ognia), jednak jej wkomponowanie w winietę Brigantia c. sugeruje, że rysownik miał świadomość istnienia w tym miejscu takiej właśnie budowli. Wreszcie ostatnia $\mathrm{z}$ analizowanych tutaj map, datowana w przedziale lat 1276-1305 mapa z Hereford (tab. I/6) 77 , posiada na zachodnich kresach ekumeny wielką, dwupiętrową latarnię morską, na szczycie której płonie ogień. Wieża ta styka się bezpośrednio z linią brzegową, podobnie jak to miało miejsce w przypadku mapy Beatusa z Burgo de Osma, mapy Lamberta z SaintOmer oraz mapy z Psałterza Londyńskiego. Jest to solidna konstrukcja, której dolna część została wykonana z potężnych kamiennych ciosów. Nad latarnią znajduje się toponim: Perona. Scott D. Westrem uważa, że ,this beacon may be more metaphoric than literal, however: the toponym seems to refers to Padrón, the place on the Ulla river near the coast of northwest Iberia where a boat miraculously brought the apostle Jame's body from Jerusalem"78. Jeśli przyjąc powyższą sugestię, wówczas można odnieść wrażenie, że średniowieczny kartograf użył tej samej symboliki, jaka była stosowana w okresie cesarstwa na pogańskich i wczesnochrześcijańskich monumentach grobowych, analizowanych wyżej - połączył latarnię morską z tradycją funeralną. Autor tej winiety mógł, ale nie musiał, znać tradycję chrześcijańską epoki cesarstwa. Znał on natomiast z pewnością symboliczną interpretację

Eurasia in Medieval Cartography, s. 151-161 (X 11). Źródło kopii: https://www.uni-lueneburg.de/hyperimage/EbsKart/start.html (dostęp: 21.12.2018). Por. J.A. Wendt, Skarby kartografi, red. L. Szaniawska, Warszawa 2013, 56.

77 Mapa z Hereford. Źródło oryginału: Hereford, The New Library at Hereford Cathedral (data powstania: 1276-1305; wielkość oryginału: 1626 x $1346 \mathrm{~mm}$ ). Tekst legend mapy: M.F. le Vicomte de Santarem, Essai sur l'histoire de la cosmographie et de la cartographie pendant le Moyen-Âge, t. 2, Paris 1852, 288-434; Bevan - Phillott, Mediaeval Geography, passim; K. Miller, Mappaemundi. Die ältesten Weltkarten, t. 4, Stuttgart 1896; S.D. Westrem, The Hereford Map. A Transcription and Translation of the Legends with Commentary, Terrarum Orbis 1, Turnhout 2001. Fragmenty tekstu legend mapy: J. Lelewel, Géographie du Moyen Age, t. 2, Bruxelles 1852, 6-7; Hallberg, L'Extrème Orient dans la littérature et la cartographie (nazwy geograficzne w porządku alfabetycznym); Chekin, Northern Eurasia in Medieval Cartography, s. 163-168 (X 12). Źródło kopii: C.J. Schüler, Die Geschichte der Kartographie, Paris 2010, 18. Por. Wendt, Skarby kartografii, s. 55; Brotton, Stynne mapy, s. 56.

78 Westerm, The Hereford Map, s. 326 (nr 841/komentarz). 
latarni morskiej jako drogowskazu kierującego do bezpiecznej przystani tych, którzy ,żeglują" po niebezpiecznych falach życia. Wychodząc $\mathrm{z}$ tej powszechnie znanej symboliki, autor winiety dokonał pewnego znaczącego przesunięcia akcentów. Oto bowiem płomień na szczycie latarni w zestawieniu z pobliskim sanktuarium Jakuba Apostoła, określonego tutaj jako Templum Sancti Jacobi ${ }^{79}$, nie tyle jest symbolem zbawczego portu, co słynącego łaskami miejsca spoczynku Apostoła. W tym sensie latarnia morska na mapie z Hereford może być interpretowana jako kierunkowskaz dla pielgrzymów podejmujących wyprawę do Santiago de Compostela. To przesunięcie akcentu z idei zbawienia duszy na ideę przewodniczki drogi jest zmianą istotną, ale nie rewolucyjną. Pielgrzymka była przecież traktowana właśnie jako metafora życiowej drogi, a zatem centrum pielgrzymkowe to metafora dotarcia chrześcijanina do celu tej drogi, to substytut zbawienia, w imię którego podejmowano ten trud. W ten sposób latarnia morska w La Coruña (i tylko ona) jako przewodniczka drogi pielgrzymów, by nie powiedzieć ich „Hodegetria”, otrzymała dodatkowy, lokalny element symboliczny. Motyw ten nie jest jednak zupełnym novum, ponieważ podobną graficzną sugestię można dostrzec już na mapie Beatusa z Burgo de Osma, gdzie zestawiono latarnię i sanktuarium Jakuba Starszego. Zielony kolor murów tejże latarni wzmacnia dodatkowo tę intuicję (fig. 2A i tab. I/1). Należy także pamiętać o tym, że Galicja i Asturia były prowincjami Hiszpanii, z których wyszła rekonkwista. Jej postępy sprawiły, że $\mathrm{w}$ roku 1085, a więc niemal w tym samym czasie, kiedy powstała analizowana tutaj mapa Beatusa, odbito z rąk muzułmańskich Toledo. W ten sposób można mówić o podwójnej symbolice latarni i sanktuarium św. Jakuba.

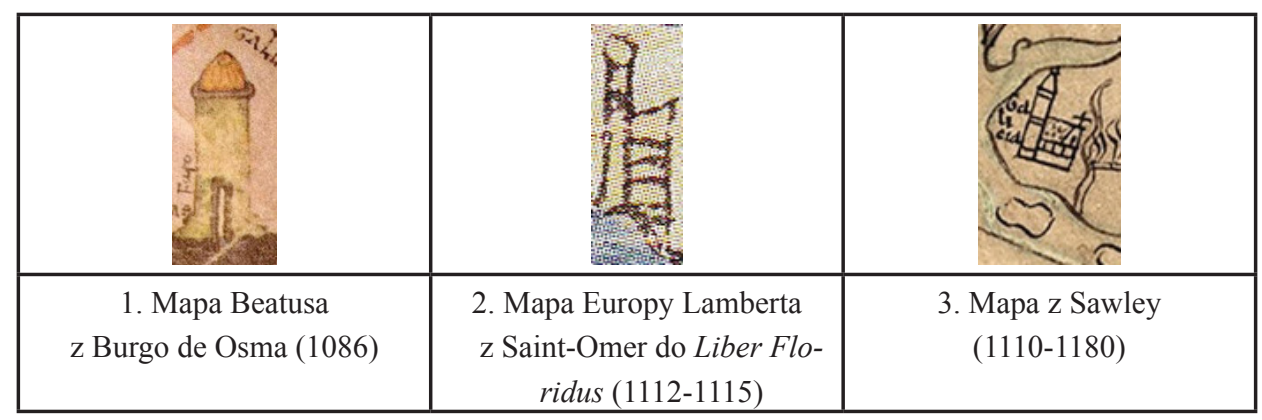

79 Westerm, The Hereford Map, s. 327 (nr 840/tekst). 


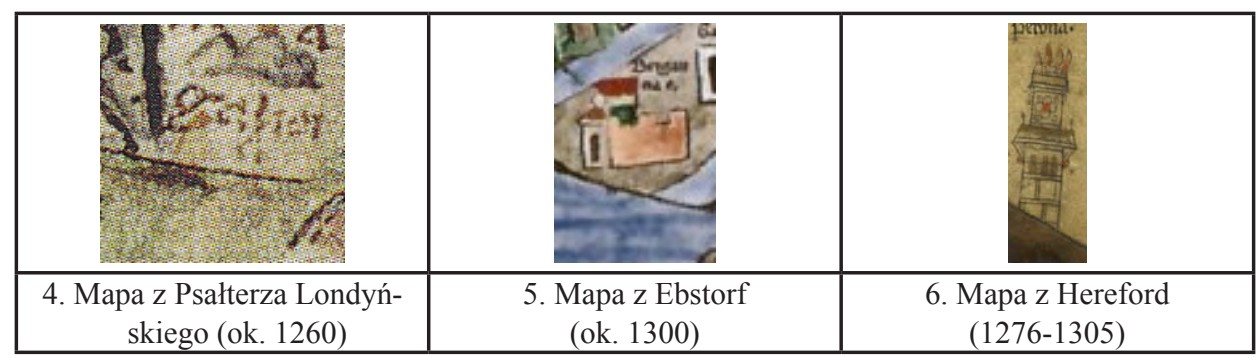

Tab. I: Najstarsze zachowane winiety latarni w La Coruña ${ }^{80}$

W okresie nowożytnym natomiast, jak to wynika z map Abrahama Orteliusza (14 IV 1527-28 VI 1598 - tab. II/1) ${ }^{81}$, Gerarda Mercatora (5 III 1512-2 XII 1594) oraz kontynuatora dzieła tego ostatniego, czyli Jodocusa Hondiusza Starszego (14 X 1563-12 II 1612 - tab. II/2A-B) ${ }^{82}$, wszelki ślad po tego typu interpretacji zanika. Latarnia i miasto stanowią tam dwa odrębne elementy przedstawione w sposób jednoznacznie schematyczny. W ich grafice nie ma cienia aluzji do średniowiecznego kontekstu symbolicznego.

\begin{tabular}{|c|c|c|}
\hline & \\
\hline $\begin{array}{c}\text { 1. Atlas Abrahama Orteliusa } \\
\text { (1572), mapa nr 7 }\end{array}$ & $\begin{array}{c}\text { 2A. Atlas Mercatora-Hondiusa } \\
\text { (1633), mapa nr 128 }\end{array}$ & $\begin{array}{c}\text { 2B. Atlas Mercatora-Hondiusa } \\
\text { (1633), mapa nr 131 }\end{array}$ \\
\hline
\end{tabular}

Tab. II: Latarnia w La Coruña na wybranych mapach nowożytnych

$* * *$

Latarnia morska w La Coruña na mapie Beatusa z Burgo de Osma nie była dotąd przedmiotem szczegółowych analiz w przedstawionym wyżej aspekcie. Traktowano ją zwykle jako element dekoracyjny tej mapy, który rysownik wprowadził w ramach swoistego ,patriotyzmu lokalnego”. Jako

80 Winiety te (z wyjątkiem schematu z mapy psałterzowej) reprodukuje również Jesús Ángel Sánchez-García: Desvelando un fantasma, s. 293, fig. 11 (mapa Europy Lamberta z Saint Omer), s. 297, fig. 13 (mapa z Hereford), s. 299, fig. 14 (mapa z Ebstorf). Por. też przyp. 18.

81 A. Ortelius, Theatrum Orbis Terrarum. Gedruck zu Nuermberg durch Joahnn Koler Anno MDLXXII, red. U. Schneider, wyd. 3, Darmstadt 2012, 24-25 (mapa nr 7).

82 G. Mercator - J. Hondius, Der Atlas. Das ist Abbildung der gantzen Welt, mit allen darin begriffenen Laendern und Provintzen: Sonderlich von Teutschland, Franckreich, Niderland, Ost und West Indien: Mit Beschreibung der selben, Amsterdam 1633, 276-277 (mapa nr 128) i 282-283 (mapa nr 131). 
duża budowla nadbrzeżna ściśle związana $\mathrm{z}$ transportem morskim była też dobrze znana ówczesnym żeglarzom. Jednak podjęta tutaj próba szerszego spojrzenia na najstarszą z zachowanych winiet kartograficznych tej latarni ${ }^{83}$ pozwoliła wskazać na jej potencjalne związki z wyobrażeniami latarń morskich na sarkofagach i płytach nagrobnych z epoki cesarstwa rzymskiego. Szczególnie ważna jest $\mathrm{w}$ tym kontekście symbolika funeralna latarni morskiej, utrwalona na płytach grobowych pochodzących z rzymskich katakumb. Latarnia jest tam niekiedy symbolem zbawienia traktowanym jako ekwiwalent krzyża, co dobrze oddaje intuicja, którą swego czasu wyraził O. Marucchi $^{84}$. Z kolei latarnia na mapie Beatusa wznosi się na zachodnich kresach znanego wówczas świata, które to obszary były najbardziej oddalone zarówno od ogrodu w Edenie na Wschodzie (Rdz 2,8), jak i od Jerozolimy, miejsca zbawczego dzieła Chrystusa. Były to więc tereny duchowego mroku, dokąd zgodnie z tradycją Dobrą Nowinę przyniósł Jakub Starszy. Wraz z nim na obszarach spowitych dotąd ciemnością śmierci zapłonęła nadzieja zbawienia, czego graficznym wyrazem na mapie z Burgo de Osma jest zestawienie latarni i sanktuarium Apostoła. Na kresach Zachodu powstała w ten sposób bezpieczna duchowa przystań. Nie przypadkiem mapa ta została sporządzona w kręgu zakonnej kultury benedyktyńskiej, gdzie przechowywano pieczołowicie dawną chrześcijańską tradycję. Winietę latarni należy również łączyć z graficznym motywem przewodnim tej właśnie mapy Beatusa, a mianowicie z motywem ,rozesłania Apostołów”. Dzięki temu właśnie wyeksponowano rolę św. Jakuba i jego pielgrzymkowego sanktuarium w Santiago de Compostela, którego symbolem miała się stać świątynia budowana od roku 1075 z inicjatywy króla Alfonsa VI Mężnego (1040-1 VII 1109; początek panowania: 1065). Jednak sam morski szlak pielgrzymkowy, wiodący z Brytanii i Irlandii do Composteli przez port w rzymskim

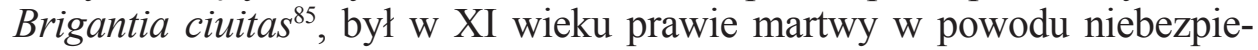
czeństwa, jakie stanowili na tych wodach Normanowie ${ }^{86}$. Pielgrzymi wybierali wówczas o wiele bezpieczniejszą trasę lądową. Nie należy zatem łączyć wprost winiety latarni na mapie Beatusa z Burgo de Osma z morskim szlakiem pielgrzymim do Composteli, lecz trzeba raczej widzieć w niej symbol przewodniczki drogi, „Hodegetrii”. Pielgrzymka do Composteli i życiowa

83 Por. Hutter, Der römische Leuchtturm von La Coruña, s. 16. Autor wskazuje, że jest to w ogóle najstarszy istniejący dziś obraz tej latarni. Por. też: Hutter, El faro romano de la Coruña, s. 31.

84 Por. przyp. 53.

85 Por. przyp. 14.

86 Por. F.A. Otero, Santiago y los caminos de Santiago: un paisaje cultural, una cultura de paisaje, „Boletín de la Asociación de Géografos Españoles” 51 (2009) 208; Sánchez-García: Desvelando un fantasma, s. 284-286. 
droga chrześcijanina, której celem jest zbawienie duszy, tworzą tutaj symboliczną jedność. Jest to zatem rodzaj graficznej katechezy ${ }^{87}$, która łączy najbardziej czcigodne idee chrześcijaństwa okresu prześladowań i męczeństwa, wywodzące się z Rzymu, z ideami „Jakubowego” ruchu pielgrzymkowego, oblekając ten ruch w piękną szatę wielkiej wczesnochrześcijańskiej tradycji. Mapa ta w kontekście benedyktyńskiej stabilitas loci zyskuje jeszcze jeden ważny element, a mianowicie służy duchowemu pogłębieniu idei peregrinatio in stabilitate ${ }^{88}$.

\title{
Winieta latarni morskiej w La Coruña na mapie Beatusa z Burgo de Osma w kontekście symboliki wczesnochrześcijańskiej
}

\author{
(streszczenie)
}

\begin{abstract}
Niniejszy artykuł porównuje winietę latarni morskiej z La Coruña, która znajduje się na mapie Beatusa z Burgo de Osma, z latarniami morskimi wyrzeźbionymi na reliefach sarkofagów i płyt nagrobnych w epoce cesarstwa rzymskiego oraz z winietami tejże latarni na innych zachowanych mapach średniowiecznych. W ten sposób starano się wskazać na ideowe pokrewieństwo pomiędzy tymi elementami. Latarnia morska na reliefach pogańskich sarkofagów jest symbolem szczęśliwego portu, do którego zmierza ludzka dusza. Z kolei latarnia morska na chrześcijańskich płytach grobowych, odnalezionych w rzymskich katakumbach, jest symbolem zbawienia, traktowanym niekiedy jako ekwiwalent krzyża. Latarnia na mapie z Burgo de Osma znajduje się na zachodnich kresach znanego wówczas świata, które to obszary były najbardziej oddalone zarówno od ogrodu w Edenie na Wschodzie, jak i od Jerozolimy, miejsca zbawczego dzieła Chrystusa. Były to więc tereny duchowego mroku, dokąd zgodnie z tradycją Jakub Starszy przyniósł światło Ewangelii. Wraz z nim na obszarach, gdzie dotąd panowała śmierć, zapłonęła nadzieja zbawienia, czego graficznym wyrazem na analizowanej mapie Beatusa jest zestawienie latarni morskiej z sanktuarium Apostoła. W ten sposób na kresach Zachodu powstała najpierw bezpieczna duchowa przystań, a później wielkie centrum pielgrzymkowe rozświetlające duchowe mroki tej peryferyjnej części ówczesnego świata. Nie przypadkiem mapa ta została wykonana w kręgu klasztornej kultury benedyktyńskiej, która przechowywała pieczołowicie dawną chrześcijańską tradycję.
\end{abstract}

87 Podobny pogląd wyraziła swego czasu Margherita Guarducci (20 XII 1902-2 IX 1999) w kontekście mozaiki podłogowej z Qasr el-Lebye datowanej na rok 539, której jeden z pięćdziesięciu paneli przedstawia latarnię morską. Mozaikę tę odnaleziono w ruinach północno-afrykańskiej bazyliki chrześcijańskiej. Włoska badaczka uważała, że owe mozaikowe panele tworzą rodzaj starochrześcijańskiej, ilustrowanej katechezy. M. Guarducci, La più antica catechesi figurata. Il musaico di Gasr Elbia in Cirenaica, „Atti della Academia Nazionale dei Lincei. Memorie della Classe di Scienze Morali, Storiche e Filologiche" Serie VIII, 18 (1975) z. 7, 659-686. Por. Quet, Pharus, s. 806, przyp. 46.

88 Por. Sáenz-López Pérez, Peregrinatio in stabilitate, passim. 
Słowa kluczowe: chrześcijańska symbolika latarni morskiej; mapa Beatusa z Burgo de Osma; reliefy sarkofagów; reliefy płyt grobowych; mapy średniowieczne

\title{
The Vignette of the Lighthouse in La Coruña on the Map of Beatus from Burgo de Osma in the Context of Early Christian Symbolics
}

\author{
(summary)
}

The purpose of this article is to compare the vignette of the lighthouse of La Coruña, which is on the map of Beatus from Burgo de Osma, with the lighthouses carved on reliefs of sarcophagi and tombstones in the epoch of the Roman Empire and with the vignettes of this lighthouse on other surviving medieval maps. In this way, to point out the ideological kinship between these elements. The lighthouse on the reliefs of pagan sarcophagi is the symbol of the happy port to which the human soul is heading. In turn, the lighthouse on Christian grave plates, found in the Roman catacombs, is a symbol of salvation, sometimes treated as the equivalent of the cross. The lighthouse on the map of Burgo de Osma is located on the western border of the world known at that time, which areas were the most remote from both the garden in Eden in the East and from Jerusalem, the place of salvific work of Christ. So these were areas of spiritual darkness, where, according to tradition, Jakub the Elder brought the light of the Gospel. With his arrival, in the areas where death reigned so far, the hope of salvation flared, which is illustrated graphically on the analyzed Beatus map by the lighthouse, which is near the Apostle's sanctuary. In this way, a safe spiritual haven was first established on the western periphery of the then known world, which over time became a great pilgrimage center. It is no coincidence that this map was made in the circle of the monastic Benedictine culture, which carefully preserved the old Christian tradition.

Keywords: the Christian symbolism of the lighthouse; map of Beatus from Burgo de Osma; medieval maps; reliefs of sarcophagi; reliefs of tombstones

\section{Bibliografia}

\section{Źródła}

Beati in Apocalipsin libri duodecim, red. H.A. Sanders, Papers and Monographs of the American Academy in Rome 7, Rome 1930.

Beatus Liebanensis, Tractatus de Apocalipsin, red. R. Gryson - M.-C. Bièvre, CCL 107BC, Turnhout 2012.

Cosmographia, w: Geographi Latini Minores, ed. A. Riese, Heilbronn 1878, 71-103.

La „Descriptio mappe mundi” de Hugues de Saint-Victor. Texte inédit avec introduction et commentaire, red. P. Gautier Dalché, Collection des Études Augustiniennes. Série Moyen Âge et Temps Modernes [20], Paris 1988. 
Geographi Latini Minores, ed. A. Riese, Heilbronn 1878.

Gervase of Tilbury, Otia imperialia, red. S.E. Banks - J.W. Binns, Oxford Medieval Texts, Oxford 2002.

The Old English Orosius, red. J. Bately, Early English Text Society. Supplementary Series 6, Oxford 1980.

Orosius, Historia adversus paganos, red. K. Zangemeister, w: Orosius, Historia adversus paganos. Liber apologeticus, CSEL 5, Wien 1882.

Orosius, Historiarum adversus paganos libri primi caput alterum, w: Geographi Latini Minores, ed. A. Riese, Heilbronn 1878, 56-70.

Sancti Beati a Liebana Commentarius in Apocalypsin, ed. E. Romero Pose, t. 1-2, Romae 1985.

Sancti Beati, Presbyteri Hispani Liebanensis, in Apocalypsin, ac plurimas utriusque Foederis paginas commentaria, ex veteribus, nonnullisque desideratis Patribus, mille retro annis collecta, nunc primum edita, ed. H. Florey, Matriti 1770.

Situs orbis terre vel regionum: Un traité de géographie inédit du haut Moyen Âge (Paris, B. N. Latin 4841), red. P. Gautier Dalché, ,Revue d'Histoire des Textes” 12-13 (19821983) 149-179.

\section{Opracowania}

Amedick R, Die Sarkophage mit Darstellungen aus dem Menschenleben, cz. 4, Die antiken Sarkophagreliefs I/4, Berlin 1991.

Apocalipsis Beati Liebanensis Burgi Oxomensis, t. 2, tł. A. Baloira, Valencia 1992.

Bachofen J.J., Römische Grablampen nebst einigen andern Grabdenkmälern vorzugsweise einiger Sammlung. Tafelband, Basel 1890.

Barbarzak D., Herkules $i$ Gerion, królowie Hiszpanii. Mit i jego recepcja w iberyjskich kronikach doby średniowiecza i nowożytności, ,Symbolae Philologorum Posnaniensium Graecae et Latinae" 28 (2018) nr 2, 89-125.

Baumgärtner I., Visualisierte Weltenräume. Tradition und Innovation in den Weltkarten der Beatustradition des 10. bis 13. Jahrhunderts, w: Tradition, Innovation, Invention. Fortschrittsverweigerung und Fortschrittsbewusstsein im Mittelalter, red. H.-J. Schmidt, Scrinium Friburgense 18, Berlin - New York 2005, 231-276.

Baumgärtner I., Graphische Gestalt und Signifikanz. Europa in den Weltkarten des Beatus von Liébana und des Ranulf Hidgen, w: Europa im Weltbild des Mittelalters. Kartographische Konzepte, red. I. Baumgärtner - H. Kugler, Orbis Mediaevalis 10, Berlin 2008, 81-132.

Bello Diéguez J.M., La Edad Media: El recuerdo del Faro y el uso como Fortaleza, w: Ciudad y Torre. Roma y la Ilustración en La Coruña, La Coruña 1991, 179-180.

Bello Diéguez J.M., La Torre despues de la Reforma, w: Ciudad y Torre. Roma y la Ilustración en La Coruña, La Coruña 1991, 194-214. 
Besnier M., Pharus, w: Dictionnaire des Antiquités Grècques et Romaines, red. G. Daremberg - E. Saglio, t. IV/1, Paris 1873, 427-432.

Bevan W.L. - Phillott H.W., Mediaeval Geography: An Essays in Illustration of the Hereford Mappa Mundi, London 1873.

Bisconti F., Mestieri nelle catacombe romane. Appunti sul declino dell'iconografia del reale nei cimiteri cristiani di Roma, Studi e Ricerche 2, Città del Vaticano 2000.

Boldetti M.A., Osservazioni sopra i cimiteri de' sancti martiri ed antichi Cristiani di Roma, Lib. 1, Roma 1720.

Bolman E.S., De coloribus: The Meanings of Color in Beatus Manuscripts, „Gesta” 38 (1999) $\mathrm{nr}$ 1, 22-34.

Braun E., Antike Marmorwerke. Erste und zweite Decade, Leipzig 1843.

Brincken A.-D. Von den, Fines Terrae. Die Enden der Erde und der vierte Kontinent auf mittelalterlichen Weltkarten, Monumenta Germaniae Historica. Schriften 36, Hannover 1992.

Brincken A.-D. Von den, Studien zur Universalkartographie des Mittelalters, red. T. Szabó, Veröffentlichungen des Max-Planck-Instituts für Geschichte 229, Göttingen 2008 .

Brotton J., Stynne mapy, red. L. Szaniawska, Warszawa 2016.

Chekin L.S., Northern Eurasia in Medieval Cartography. Inventory, Text, Translation, and Commentary, Terrarum Orbis 4, Turnhout 2006.

Chico Picaza J. - Massip Bonet F., Historia sztuki świata, t. 2, tł. D. Bartnik - B. Gutowska-Nowak, Warszawa 1999.

Ciudad y Torre. Roma y la Ilustración en La Coruña, La Coruña 1991.

Collignon M., Essai sur les monuments grecs et romains relatifs au mythe de Psyché, Bibliothèque des Écoles Françaises d'Athène et de Rome 2, Paris 1877.

Costa T., To the Lighthouse: Sentinels at the Water's Edge, w: Art and Identity at the Water's Edge, red. T. Cusack, Farnham 2012, 87-105.

Deitmaring U., Die Bedeutung von rechts und links in theologischen und literarischen Texten bis um 1200, „Zeitschrift für Deutsches Altertum und Deutsche Literatur” 98 (1968) 265-292.

Destombes M., Mappemondes A.D. 1200-1500. Catalogue prepare par la Commission des Cartes Anciennes de l'Union Géographique Internationale, Monumenta Cartographica Vetustioris Aevi I, Amsterdam 1964.

Deswarte T., Géographie sacrée ou géographie du sacré? Les mappemondes du Commentaire de Beatus aux $X^{e}$ et XI siècles, w: De l'espace aux territoires: la territorialité des processus sociaux et culturels au Moyen Âge, Actes de la table ronde des 8-9 juin 2006, CESM (Poitiers), red. S. Boissellier, Culture et Société Médiévales 19, Turnhout 2010, 113-131.

Die Ebstorfer Weltkarte. Kommentierte Neuausgabe in zwei Bänden, t. I/2, red. H. Kugler - S. Glauch - A. Willing, Berlin 2007. 
Ehler E., Figürliche Loculusplatten aus dem frühchristlichen Rom, t. 1, Marburg 2012(= https://archiv.ub.uni-marburg.de/diss/z2012/0956/pdf/dee.pdf [dostęp: 20.01.2019]).

Ehler E., Figürliche Loculusplatten aus dem frühchristlichen Rom, t. 2, Marburg 2012 (= https://archiv.ub.uni-marburg.de/diss/z2012/0956/pdf/def.pdf [dostęp: 20.01.2019]).

English B., Ordo orbis terrae. Die Weltsicht in den Mappae mundi der frühen und hohen Mittelalters, Orbis Mediaevalis 3, Berlin 2002.

Fabretti R., Inscriptivm antiqvorvm quae in aedibvs paternis asservantur explicatio et additamentvm, Romae 1699.

Galichian R., Countries south of the Caucasus in Medieval Maps. Armenia, Georgia and Azerbaijan, London 2007.

García-Aráez H., Los Mapamundis de los Beatos. Origen y características principales, „Miscelánea Medieval Murciana” 18 (1993-1994) 49-76.

García-Aráez H., Los mapamundis de los Beatos, cz. 2, „Miscelánea Medieval Murciana" 19-20 (1995-1996) 97-128.

García Iglesias J.M., El mapa de los Beatos en la pintura mural románica de San Pedro de Rocas, „Archivos Leonenses” 69 (1981) 73-87.

Garrucci R., Storia della arte cristiana nei primi otto secoli della Chiesa, t. 5, Prato 1879.

Garrucci R., Storia della arte cristiana nei primi otto secoli della Chiesa, t. 6, Prato 1880.

Giardina B., Navigare necesse est: Lighthouses from Antiquity to the Middle Ages, British Archaeological Reports. International Series 2096, Oxford 2010.

Giardina B., Navigare necesse est: il faro tra mondo antico e medioevo, „Histria Antiqua" 21 (2012) 443-457.

González García F.J., Hércules contra Gerión. Mitos y legendas de la Torre de Hércules, t. 2, La Coruña 1998.

González García F.J., The Legendary Traditions about the Tower of Hercules (A Coruñn, Spain), „Folklore” 125 (2014) nr 3, 306-321.

Grabar A., Recherches sur les sources juives de l'art paléochrétien, cz. 2, „Cahiers Archéologiques" 12 (1962) 115-152.

Guarducci M., La più antica catechesi figurata. Il musaico di Gasr Elbia in Cirenaica, „Atti della Academia Nazionale dei Lincei. Memorie della Classe di Scienze Morali, Storiche e Filologiche" Serie VIII, 18 (1975) z. 7, 659-686.

Hallberg I., L'Extrème Orient dans la littérature et la cartographie de l'Occident des $X I I I^{e}, X I V^{e}$ et XV siècles. Études sur l'histoire de la géographie, Göteborg 1906.

Hauschild T., Der römischen Leuchtturm von La Coruña (Torre de Hercules). Probleme seiner Rekonstruktion, „Madrider Mitteilungen” 17 (1976) 238-257.

Hauschild T., El faro romano de La Coruña (Torre de Hércules). Problemas de su reconstrucción, tł. M.L. Cortés, w: El faro romano de la Coruña, S. Hutter - T. Hauschild, La Coruña 1991, [91]-[110].

Hutter S., Der römische Leuchtturm von La Coruña, Madrider Beiträge 3, Mainz 1973.

Hutter S., El faro romano de la Coruña, tł. F. Urgorri Casado, w: El faro romano de la Coruña, S. Hutter - T. Hauschild, La Coruña 1991, 13-90. 
Hutter S. - Hauschild T., El faro romano de la Coruña, La Coruña 1991.

Kaufmann C.M., Handbuch der altchristlichen Epigraphik, Freiburg im Breisgau 1917.

King G.G., Divagations on the Beatus, „Art Studies. Medieval Renaissance and Modern” 8 (1930) nr 1, 3-58.

Klein P.K., Beatus de Liébana, Codex Urgellensis. Kommentarband zur Facsimile-Ausgabe, Madrid 2001.

Kochanek P., „Rozestanie Apostołów” na mapie Beatusa z Burgo de Osma, w: Fructus Spiritus est Caritas, Księga Jubileuszowa ofiarowana Księdzu Profesorowi Franciszkowi Draczkowskiemu z okazji siedemdziesiatej rocznicy urodzin, czterdziestolecia święceń kapłańskich i trzydziestopięciolecia pracy naukowej, red. M. Wysocki, Lublin 2011, 703-745.

Kochanek P., Iluzja schematów choro- i topograficznych jako baza mnemotechnicznej portolany $w$ starożytności, w: Tworzenie iluzji społecznej - wiedza w sferze publicznej, red. J. Szymczyk - M. Zemła - A. Jabłoński, Studia nad Wiedzą 5, Lublin 2012, 73-126.

Kochanek P., Wpływ starożytnej schematyzacji mnemotechnicznej na średniowieczna i wczesno-nowożytna kartografie, ,,Vox Patrum” 38 (2018) t. 69, 285-375.

Kraus F.X., Geschichte der christlichen Kunst, Freiburg im Breisgau 1896.

Lanciani R., Ricerche topografiche sulla città di porto, „Annali dell'Istituto di Corrispondenza Archeologica" 40 (1868) 144-195.

Leclercq H., Ame, w: DACL, t. I/1, Paris 1907, 1470-1554.

Leclercq H., Gordien et Épimaque, w: DACL, t. VI/1, Paris 1925, 1379-1381.

Leclercq H., Phare, w: DACL, t. 14/1, Paris 1939, 671-673.

Lecoq D., La Mappemonde de „Liber Floridus” ou la Vision du Monde de Lambert de Saint-Omer, „Imago Mundi” 39 (1987) 9-49.

Lecoq D., La mappemonde d'Henri de Mayence ou l'image du monde au XII siècle, w: Iconographie médiévale. Image, texte, contexte, red. G. Duchet-Suchaux, Paris 1990, 155-207.

Lelewel J., Géographie du Moyen Age, t. 2, Bruxelles 1852.

Lichtenberger A., Glück und Gefahr - Ambivalente Meereserfahrung in der Bildwelt römischer Sarkophage, w: Das Mittelmeer und der Tod, red. A. Berner - J.-M. Henke - A. Lichtenberger - B. Morstadt - A. Riedel, Mittelmeerstudien 13, Paderborn 2016, 495-509.

Mamachi T.M., Originum et antiquitatum christianorum libri XX, t. 3, Romae 1751.

Martigny J.A., Dictionnaire des antiquités chrétiennes, Paris 1877.

Martin T. - Williams J., Women's Spaces - Real and Imagined - in the Illustrated Beatus Commentaries, „Arenal” 25 (2018) nr 2, 357-396.

Martínez Maganto J., Faros y luces de señalizacion en la navegacion antiqua, „Cuadernos de Prehistoria y Arqueología” 17 (1990) 67-89.

Marucchi H., Éléments d'archéologie chrétienne. Notions générales, Paris - Rome 1899. 
Marucchi O., Epigrafia cristiana. Trattato elementare con una silloge di antiche iscrizioni cristiane principalmente di Roma, Milano 1910.

Marucchi O., I monumenti del Museo Cristiano Pio-Lateranense, Milano 1910.

Marucchi O., Handbuch der christlichen Archäologie, red. F. Segmüller, Einsiedeln Waldshut - Cöln 1912.

Marucchi O., Il recente scavo sotto il monastero dei Trapisti, RivAC 4 (1927) z. 1-2, 103 114.

Marucchi O., Manuale di archeologia cristiana, red. G. Belvederi, wyd. 4, Roma 1933.

Matz F. - Duhn F. von, Antike Bildwerke in Rom mit Ausschluss der grösseren Sammlungen, t. 2, Leipzig 1881.

Menendez-Pidal G., Mozárabes y Asturianos en la cultura de la alta Edad Media en relación especial con la historia de los conocimientos geográficos, „Boletin de la Real Academia de la Historia" 134 (1954) 137-291.

Mercator G. - Hondius J., Der Atlas. Das ist Abbildung der gantzen Welt, mit allen darin begriffenen Laendern und Provintzen: Sonderlich von Teutschland, Franckreich, Niderland, Ost und West Indien: Mit Beschreibung der selben, Amsterdam 1633.

Miller K., Mappaemundi. Die ältesten Weltkarten, t. 1, Stuttgart 1895.

Miller K., Mappaemundi. Die ältesten Weltkarten, t. 3,Stuttgart 1895.

Miller K., Mappaemundi. Die ältesten Weltkarten, t. 4, Stuttgart 1896.

Miller K., Mappaemundi. Die ältesten Weltkarten, t. 5, Stuttgart 1896.

Moralejo Alvarez S., Mapa de la diáspora apostólica en San Pedro de Rocas: Notas para su interpretación y filiación en la tradición cartográfica de los „,Beatos”, „Compostellanum" 31 (1986) nr 3-4, 315-340.

Moralejo Alvarez S., El mundo y el tiempo en el mapa de Beato de Osma, w: Apocalipsis Beati Liebanensis Burgi Oxomensis, tł. A. Baloira, Valencia 1992, 151-179.

Neuss W., Die Apokalypse des Hl. Johannes in der altspanischen und altchristlichen Bibel-Illustration (Das Problem der Beatus-Handschriften), t. 1-2, Spanische Forschungen der Görresgesellschaft Reihe II/2-3, Münster 1931.

Noguera Celdrán J.M., Instalaciones portuarias romanas: representaciones iconográficas y testimonio histórico, „Anales de Prehistoria y Arqueología” 11-12 (1995-1996) 219-235.

Nurminen M.T., Die Welt in Karten. Meisterwerke der Kartographie, tł. G. Beitscher G. Seidel, Darmstadt 2017.

Nussbaum O., Die Bewertung von rechts und links in der römischen Liturgie, JbAC 5 (1962) 158-171.

Ortelius A., Theatrum Orbis Terrarum. Gedruck zu Nuermberg durch Joahnn Koler Anno MDLXXII, red. U. Schneider, wyd. 3, Darmstadt 2012.

Otero F.A., Santiago y los caminos de Santiago: un paisaje cultural, una cultura de paisaje, „Boletín de la Asociación de Géografos Españoles” 51 (2009) 203-218.

Patrimonio artístico de Galicia y otros estudios. Homenaje al Prof. Dr. Serafín Moralejo Álvarez, vol. 2, red. M.Á. Franco Mata, Santiago de Compostela 2004. 
Perišić M., Lighthouses as a part of tourist offer being specific tourist destination, w: Interdisciplinary Management Research V. The J.J. Strossmayer University of Osijek, Faculty of Economics in Osijek, red. D. Barković, Osijek 2009, 381-395.

Perret L., Catacombes de Rome, t. 5, Paris 1851.

Picard Ch., Sur quelques représentations nouvelles du phare d'Alexandrie et sur l'origine alexandrine des paysages portuaires, „Bulletin de Correspondance Hellénique” 76 (1952) 61-95.

Pijoan J., Sztuka islamu, w: Sztuka świata, t. 4, tł. R. Kalicki - B. Ostrowska, Warszawa 1990, 205-251.

Poeschke J., Leuchtturm, w: Lexikon der christlichen Ikonographie, t. 3, wyd. 2, Rom Freiburg im Breisgau 1994, 92-93.

Quet M.-H., Pharus, „Mélanges de l'École Française de Rome. Antiquité” 96 (1984) z. 2, 789-845.

Raoul-Rochette D., Deuxième Mémoire sur les Antiquités chrétiennes des Catacombes:

Pierres sépulcrales envisagées sous le double rapport des formules et des symboles funéraires, w: Mémoires de l'Institut Royal de France. Académie des Inscriptions et Belles-Lettres, vol. XIII/1, Paris 1837, 170-265.

Reddé M., La représentation des phares à l'époque romain, „Mélanges de l'École Française de Rome. Antiquité" 91 (1979) z. 2, 845-872.

Reichert F., Das Bild der Welt im Mittelalter, Darmstadt 2013.

Reitzenstein R., Die Göttin Psyche in der hellenistischen und frühchristlichen Literatur, Sitzungsberichte der Heidelberger Akademie der Wissenschaften. Philosophisch-Historische Klasse 10, Heidelberg 1917.

Rojo Orcajo T., Catálogo descriptivo de los códices que se conservan en la Santa Iglesia Catedral de Burgo de Osma, „Boletín de la Real Academia de la Historia” 94 (1929) 655-792; 95 (1929) 152-314.

Rojo Orcajo T., Catálogo descriptivo de los códices que se conservan en la Santa Iglesia Catedral de Burgo de Osma, Madrid 1929.

Roller T., Catacombes de Rome. Histoire de l'art et des croyances religieuses pendant les premiers siècles du christianisme, vol. 1, Paris 1881.

Rossi G.B. de, Escavazioni nel cimitero di Callisto, „Bullettino di Archeologia Cristiana” 6 (1868) z. 1, 6-15.

Roszak P., Beato z Liébany i mozarabskie komentarze do Apokalipsy, BPTh 5 (2012) 125-147.

Sáenz-López Pérez S., Peregrinatio in stabilitate: transformación de un mapa de los Beatos en herramienta de peregrinación espiritual, „Anales de Historia del Arte”, Volumen Extraordinario (2011) 317-334.

Sáenz-López Pérez S., The Beatus Maps: The Revelation of the World in the Middle Ages, tt. P. Krakenberger - G. Coldham, Burgos 2014.

Saint-roch P., Le cimitière de Basileus ou Coemeterium sanctorum Marci et Marcelliani Damasique, Roma Sotterranea Cristiana 11, Città del Vaticano 1999. 
Sanchez-Garcia J.A., Desvelando un fantasma. Sobre un mapamundi árabe, la Torre de Hércules y las representaciones de faros en la cartografia medieval, „Memoria y Civilización" 20 (2017) 259-308.

Santarem M.F. le Vicomte de, Essai sur l'histoire de la cosmographie et de la cartographie pendant le Moyen-Âge, t. 2, Paris 1852.

Schulten A., Iberische Landeskunde: Geographie des antiken Spanien, wyd. 2, Baden-Baden 1974.

Schüler C.J., Die Geschichte der Kartographie, Paris 2010.

Seis estudios sobre Beatos medievales, red. M. Pérez, Leon 2010.

Shailor B.A., The Beatus of Burgo de Osma: A Paleographical and Codicological Studies, w: Apocalipsis Beati Liebanensis Burgi Oxomensis, t. 2, tł. A. Baloira, Valencia 1992, 29-52.

Sommerbrodt E., Die Ebstorfer Weltkarte, Hannover 1891.

Среднеьковье въ его памятникахъ: сборникъ переводовъ, red. Д.Н. Егорова, Москва 1913.

Stierlin H., Los Beatos de Liébana y el arte mozárabe, Madrid 1983.

Strzelczyk J., Gerwazy z Tilbury. Studium z dziejów uczoności geograficznej w średniowieczu, Monografie z Dziejów Nauki i Techniki 66, Wrocław - Warszawa 1970.

Stuhlfauth G., Der Leuchtturm von Ostia, „Mitteilungen des Deutschen Archaeologischen Instituts. Roemische Abteilung" 53 (1938) 139-163.

Stuhlfauth G., Das Schiff als Symbol der altchristlichen Kunst, RivAC 19 (1942) 111-141.

Temi di iconografia paleocristiana, red. F. Bisconti, Sussidi allo Studio delle Antichità Cristiane 13, Città del Vaticano 2000.

Thiersch H., Pharos: Antike, Islam und Occident. Ein Beitrag zur Architekturgeschichte, Leipzig und Berlin 1909.

Veitmeyer L.A., Leuchtfeuer und Leuchtapparate, München-Leipzig 1900.

Visconti C.L., Fronte di sarcofago con Tritoni, Nereidi e navi, ed altri funebri monumenti con rappresentanza di navi, „Bullettino della Commissione Archeologica Municipale" (1872-1873) 255-269.

Wendt J.A., Skarby kartografii, red. L. Szaniawska, Warszawa 2013.

Westrem S.D., The Hereford Map. A Transcription and Translation of the Legends with Commentary, Terrarum Orbis 1, Turnhout 2001.

Williams J., Las ilustraciones del Beato de Burgo de Osma, w: Apocalipsis Beati Liebanensis Burgi Oxomensis, t. 2, tł. A. Baloira, Valencia 1992, 109-150.

Williams J., Isidore, Orosius and the Beatus Map, „Imago Mundi” 49 (1997) 7-32.

Williams J., The Illustrated Beatus. A Corpus of the Illustrations of the Commentary on the Apocalypse, t. 1-5, London 1994-2003.

Williams J., Visions of the End in Medieval Spain. Catalogue of Illustrated Beatus Commentary on the Apocalypse and the Study of the Geneva Beatus, red. T. Martin, Late Antique and Early Medieval Iberia 3, Amsterdam 2017.

Yarza Luaces J., Beato de Liébana: Manuscriptos iluminados, Barcelona 1998. 


\section{Netografia}

https://arachne.dainst.org/entity/3623933 (dostęp: 5.01.2019).

https://arachne.dainst.org/entity/3623938 (dostęp: 5.01.2019).

https://arachne.dainst.org/entity/3623949 (dostęp: 5.01.2019).

https://arachne.dainst.org/entity/3623950 (dostęp: 5.01.2019).

https://arachne.dainst.org/entity/3623953 (dostęp: 5.01.2019).

https://arachne.uni-koeln.de/arachne/index.php?view[layout]=objekt_item\&search[constraints][objekt][search Seriennummer] $=28859$ (dostęp: 20.01.2019).

https://arachne.uni-koeln.de/arachne/index.php?view[layout]=objekt_item\&search[constraints][objekt][search Seriennummer]=608905 (dostęp: 20.01.2019).

https://arachne.uni -koeln.de/arachne/index.php?view[layout]=objekt_item\&search[constraints][objekt][search Seriennummer] $=608969$ (dostęp: 20.01.2019). https://archiv.ub.uni-marburg.de/diss/z2012/0956/pdf/dee.pdf (dostęp: 20.01.2019). https://archiv.ub.uni-marburg.de/diss/z2012/0956/pdf/def.pdf (dostęp: 11.01.2019). https://commons.wikimedia.org/wiki/File:WesternEurope_BeatusOsma.jpg (dostęp: 11.01.2019). https://www.edb.uniba.it/epigraphy/3531 (dostęp: 30.01.2019).

https://www.uni-lueneburg.de/hyperimage/EbsKart/start.html (dostęp: 21.12.2019). 